\title{
WELDING DEVELOPMENT FOR THE WASTE ENCAPSULATION PROGRAM \\ FINAL REPORT
}

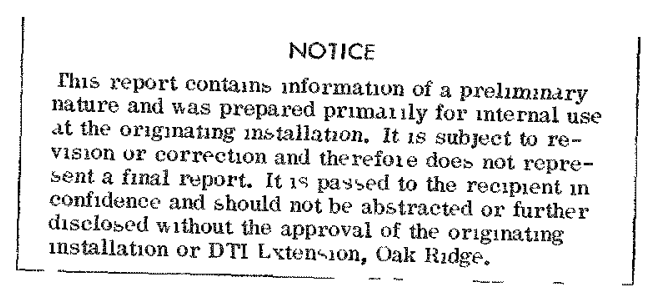

W. H. O'Brien

Welding Engineer

Process Design and Development Development Engineering Department Atlantic Richfield Hanford Company

\section{NOTICE.}

This report was prepared as an account of work sponsored by the United States Government. Neither the United States nor the United States Energy Research and Dewelopment Administrition, nor ary of their employees, nor any of their contractors, subcontractors, or their employees, makes any warranty, express or implied, or assumes any legal liability or responsibility for the accuracy, completeness or usefulnes of any information, apparatus, product or process disclosed, or represents that its use would not infringe privately owned rights.

March 1974

Prepared for the Atomic Energy Commission by Atlantic Richfield Hanford Company under Contract AT(45-1) -2130 


\section{DISCLAIMER}

This report was prepared as an account of work sponsored by an agency of the United States Government. Neither the United States Government nor any agency Thereof, nor any of their employees, makes any warranty, express or implied, or assumes any legal liability or responsibility for the accuracy, completeness, or usefulness of any information, apparatus, product, or process disclosed, or represents that its use would not infringe privately owned rights. Reference herein to any specific commercial product, process, or service by trade name, trademark, manufacturer, or otherwise does not necessarily constitute or imply its endorsement, recommendation, or favoring by the United States Government or any agency thereof. The views and opinions of authors expressed herein do not necessarily state or reflect those of the United States Government or any agency thereof. 


\section{DISCLAIMER}

Portions of this document may be illegible in electronic image products. Images are produced from the best available original document. 


\section{DISTRIBUTION}

Atomic Energy Commission Richland Operations Office
0. J. Elgert
(2)
Fed. $\quad 700$

Atlantic Richfield Hanford Company
D. Armstrong
A. E. Barber
C. R. Bergdah1
D. E. Braden
H. L. Brandt
D. A. Bruce
D. N. Berger
B. Bitney
G. C. Blackburn
G. Burton Jr.
R. DeJong
J. B. Fecht
R. C. Forsman
R. Fowler
G. J. Funnel1
D. R. Gustavson
J. E. Hammond
R. L. Hibbard
J. A. Herbolsheimer

$\begin{array}{cl}271-T & 200-W \\ \text { Fed. } & 700 \\ 2704-E & 200-E \\ 271-T & 200-W \\ 202-A & 200-E \\ 225-B & 200-E \\ 225-B & 200-E \\ 225-B & 200-E \\ 271-C R & 200-E \\ \text { Fed. } & 700 \\ 274-W & 200-W \\ 222-T & 200-W \\ 222-B & 200-E \\ 2722-W & 200-W \\ 2722-W & 200-W \\ 2704-W & 200-W \\ 2704-W & 200-W \\ 202-A & 200-E \\ 271-T & 200-W\end{array}$

D. A. Hoover

W. P. Ingalls

L. M. Knights

R. LaReviere

(2)

R. Y. Lyon

C. W. Malody

P. G. Marte 11

E. L. Moore

J. D. Moore

A. C. Morganthayler

G. A. Nicholson

G. C. Oberg

W. H. O'Brien

R. G. 01 iver

R. C. Roal

H. P. Shaw

P. W. Smith

R. M. Smithers

F. J. Sobeck

E. R. Vollert

G. R. Williams

D. D. Wodrich

R. A. Yoder

R. A. Zinsli

H. A. Zwe ifel
271-T

$271-T$

$271-B$

703

703

2704-E

274-W

$271-T$

225-B

$222-T$

$234-5$

2704-E

$271-T$

$271-T$

271-T

Fed

2704-E

$271-B$

225-B

$271-T$

271-T

2704-E

$271-T$

222-T

2704-W
200-W

200-W 200-E

700

700

200-E

200-W

$200-W$

200-E

200-W

200-W

200-E

200-W

200-W

200-W

700

200-E

200-E

200-E

200-W

200-W

200-E

200-W

200-W

200-4! 
UNCLASSIFIED

WELDING DEVELOPMENT FOR THE WASTE ENCAPSULATION PROGRAM

FINAL REPORT

( PROJECT NO. HAP-63T)

W. H. O'Brien

March 1974

Submitted by:
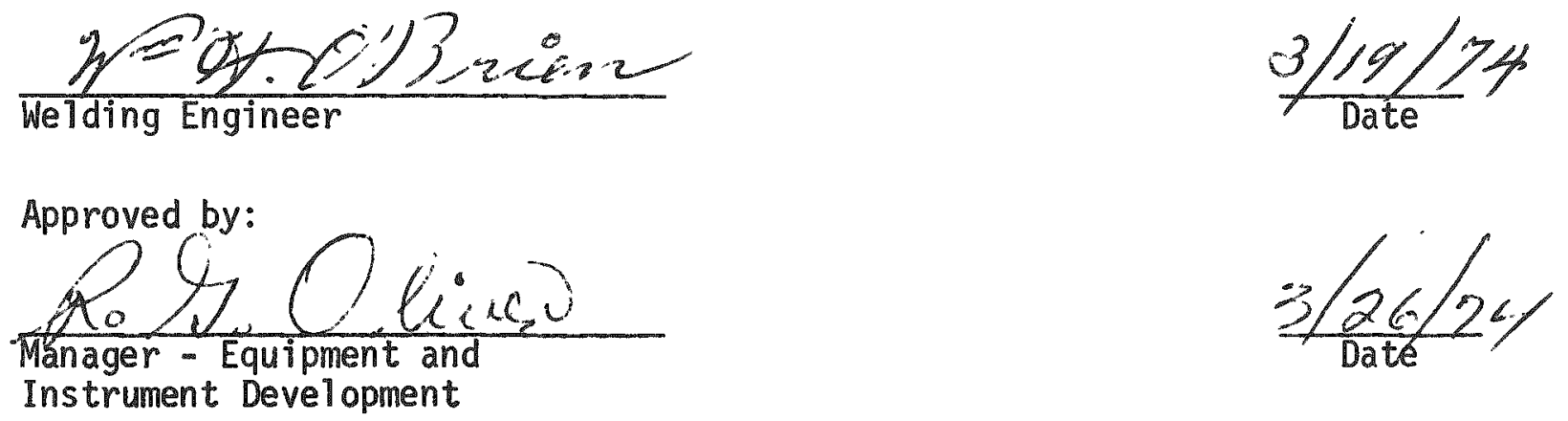

Approved by:

Dic Bradeco

Manager - Process Design and Development

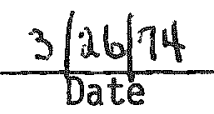


TABLE OF CONTENTS

\begin{tabular}{|c|c|}
\hline & Page \\
\hline INTRODUCTION & 4 \\
\hline ENCAPSULATION FACILITY & 4 \\
\hline WELDING EQUIPMENT & 4 \\
\hline NONDESTRUCTIVE EXAMINATION EQUIPMENT & 5 \\
\hline $\begin{array}{l}\text { HELIUM MASS SPECTROMETER } \\
\text { ULTRASONIC }\end{array}$ & $\begin{array}{l}5 \\
5\end{array}$ \\
\hline QUALIFICATION PROCEDURE & 6 \\
\hline EXAMINATION OF MATERIALS & 6 \\
\hline $\begin{array}{l}\text { Tubing } \\
\text { Plate }\end{array}$ & $\begin{array}{l}6 \\
6\end{array}$ \\
\hline NONDESTRUCTIVE EXAMINATION & 7 \\
\hline $\begin{array}{l}\text { Ultrasonic Examination } \\
\text { Helium Leak Testing }\end{array}$ & $\begin{array}{l}7 \\
7\end{array}$ \\
\hline DESTRUCTIVE TESTING & 8 \\
\hline $\begin{array}{l}\text { Rupture Tests } \\
\text { Metallography }\end{array}$ & $\begin{array}{l}8 \\
8\end{array}$ \\
\hline ACCEPTANCE CRI TERIA & 8 \\
\hline WELDING PROCEDURE DEVELOPMENT & 8 \\
\hline $\begin{array}{l}\text { Joint Design } \\
\text { Helium Storage Disc } \\
\text { Strontium Fluoride Baffle } \\
\text { Welding Parameters }\end{array}$ & $\begin{array}{l}8 \\
9 \\
9 \\
9\end{array}$ \\
\hline NONDESTRUCTIVE EXAMINATION PROCEDURE DEVELOPMENT & 10 \\
\hline $\begin{array}{l}\text { Helium Mass Spectrometer } \\
\text { Ultrasonic }\end{array}$ & $\begin{array}{l}10 \\
11\end{array}$ \\
\hline NONDESTRUCTIVE EXAMINATION & 11 \\
\hline HELIUM LEAK MASS SPECTROMETER & 11 \\
\hline Procedure Development & 11 \\
\hline
\end{tabular}


3

TABLE OF CONTENTS

ULTRASONIC

Page

Procedure Development

CALIBRATION STANDARDS

WELDING EQUIPMENT

Pulsed Current Power Supply

In-Cell Welding Fixtures

NONDESTRUCTIVE EXAMINATION EQUIPMENT

Helium Mass Spectrometer

13

Utrasonic Examination

QUALITY CONTROL

WELDING

NONDESTRUCTIVE EXAMINATION

SUMMARY

13

REFERENCES 
UNCLASSIFIED

ARH -3043

4

\author{
WELDING DEVELOPMENT FOR THE \\ WASTE ENCAPSULATION PROGRAM \\ FINAL REPORT
}

\title{
INTRODUCTION
}

In keeping with the responsibility for management of the radioactive wastes currently generated at Hanford and the stored wastes accumulated from the past production, the Atlantic Richfield Hanford Company has built a new plant facility for encapsulation of the long-lived radioisotopes Strontium-90 and Cesium-137. This new plant is designed to process the stored nitrates into Strontium Fluoride $\left(\mathrm{SrF}_{2}\right)$ and Cesium Chloride $\left(\operatorname{CsC}_{1}\right)$ and seal these solid compounds in welded steel capsules for retrievable storage in deionized water basins.

The storage capsules must be of the highest integrity to provide safe, reliable storage of the strontium and cesium compounds. The Atlantic Richfield Hanford Company has, therefore, developed the was te storage encapsulation process with particular emphasis on the use of optimum welding and nondestructive testing techniques.

Welding development activities have been periodically reported since January 30, 1970 (Interim Reports 1, 2, 3, 4). This report presents the latest developments in welding and testing techniques for remote encapsulation of the radioisotopes.

\section{ENCAPSULATION FACILITY}

The new Waste Encapsulation and Storage Facility incorporates the use of shielded manipulator operated "hot cel1s" which house the custom designed and built welding fixtures and nondestructive examination equipment. The welding and examination equipment is designed to be operated by remote control from the operating gal lery. A retrievable storage bas in has been provided for underwater storage of the finished capsules. The new plant is scheduled to begin "hot-run" operations April 1, 1974.

\section{WELDING EQUIPMENT}

Design of the in-cell welding fixtures evolved into.two basic types, vertical and horizontal. Welding of all capsule caps is performed in the horizontal welding fixtures with the exception of the "hot-cell" cap on the inner cesium capsule which is welded in the vertical fixture. 
By incorporating the use of a baffle in the inner Hastelloy capsule to prevent the $\mathrm{SrF}_{2}$ compound from coming in contact with the back side of the weld joint, welding is accomplished with the strontium inner-capsule in the horizontal position. Welding of the cesium inner-capsule is performed with the capsule in the vertical position to facilitate cleaning of the joint prior to welding in the event of contamination from the cesium compound during the filling operation.

Water cooling of the torch was found to be unnecessary during the short weld cycle and so was eliminated, thus, simplifying the design and services required. The use of a compressed air system to actuate the chuck collet was also eliminated and replaced with a mechanical leverage, thereby, further simplifying the design and minimizing the potential for leakage of air or water components exposed to "hot ce 17" environment. A redesign of the top cap to incorporate the pressure relief hole into the weld joint has eliminated the need for the relief hole (purge hole) welding fixture.

The commercially available pulsed current type welding machines equipped with automatic programmers and strip chart recording instruments are located outside the "hot ce11" in the operating gallery and are being used essentially as purchased with little or no modification. A comprehensive calibration was performed on each of these machines and a detailed, stepby-step procedure was written and incorporated into the operations manual. A periodic calibration test is required in production to assure consistent, high quality performance at all times.

\section{NONDESTRUCTIVE EXAMINATION EQUIPMENT}

\section{HELIUM MASS SPECTROMETER}

Commercially available helium leak detection equipment is used to test each completed inner-capsule to determine material and weld integrity. This equipment is located in the operating gallery with vacuum lines extending through the cell wall and connected to a special design chamber in which the capsule is placed for testing.

\section{ULTRASONIC}

The ultrasonic examination equipment consists of commercially available ultrasonic examination apparatus capable of " $X Y$ " or " $C$ " scan mode of examination. The "XY" scan is performed in the standard scanner tank which is located outside the "hot cell" in the operating gallery. The " $\mathrm{C}$ " scan apparatus is a special design tank which is located in the hot cell. Examination in the " $\mathrm{C}$ " scan tank is performed by remote control utilizing the pulse-echo producing electronic recording apparatus and the cathode ray tube display unit used on the "XY" scanner. 
QUALIFICATION PROCEDURE

\section{EXAMINATION OF MATERIALS}

Tubing

1. Stainless Steel - Type 316-L

The 316-L tubing used to fabricate the cesium chloride capsule was purchased in accordance with the ARHCO material specification HWS-8835 REV. 1. Within the scope of the specification, the tubing was ultrasonically examined in accordance with the specifications of Hanford Standard HWS-8070-S and subjected to chemical analysis and mechanical properties examinations in accordance with the American Society for Testing Materials Standards and Specifications A-262-64T, $A-450-66$ and $E-112-63$.

2. Has telloy C-276

The Hastell loy tubing used to fabricate the strontium fluoride capsule was purchased in accordance with the ARHCO material specification HWS-8834-REV. 1. Testing for chemical composition, corrosion resistance and mechanical properties was performed in accordance with and did meet the requirements of this specification. Ultrasonic examination was performed in accordance with the Hanford Standard HWS-8070-S.

Plate

1. StainTess Stee1 - Type 316-L

The 316-L plate material used to fabricate the end caps on the cesium chloride capsule was purchased in accordance with the Hanford Material Specification HWS-8067-S. Within the scope of this specification, this material was tested for corrosion resistance, chemical composition and heat treatment, and mechanical properties.

2. Hastelloy $\mathrm{C}-276$

The $\mathrm{C}-276 \mathrm{plate}$ material used to fabricate the end caps on the strontium fluoride capsule was purchased in the solution-annealed condition and certified to be in conformance with the chemical composition and mechanical properties set forth in Table 1 and Table 2 of ASME case 1410 (special ruling).

3. The Hastelloy and the stainless steel plate material was purchased wi thout ultrasonic examination. The material was purchased in the plate form, then die-punched to provide blanks for the end caps. 
A random check for internal defects, by ultrasonic examination, was performed on the blanks as received. Each cap will receive a 100 percent visual and ultrasonic examination after machining.

\section{NONDESTRUCTIVE EXAMINATION}

UTtrasonic Examination

Qualification of the ultrasonic examination was accomplished by comparing the recorded $C$ Scan and $X Y$ scan to the macro-examination of each of the fifteen burst-tested capsules as shown in Figures 1 through 15.

The original development work with ultrasonic examination had been conducted under the impression that the minimum flaw size $(0.005$ in diameter of the flat bottom hole drilled in the test standard) detectable by the purchased equipment, could be extrapolated in terms of a quantitative measurement of lack of penetration. Latest developments, however, have shown that a typical recording, either XY or C scan, will display a trace of an area of lack of penetration which appears as an irregular band or circle. The width of this trace not only appears irregular, but it is aiso an enlargement of the actual flaw size by a factor of approximately two to one. A comparison of the photo-macrographs of the test capsule weld nugget with the ultrasonic examination record, as shown in Figures 1 through 15, provides evidence that a quantitative measurement of lack of penetration in the closure weld of the waste storage capsule by ultrasonic examination is not practical.

The burst-rupture tests were conducted as a means to produce comparative data by which to establish test standards and acceptance criteria. As a result of these tests, data was generated, as shown in Figures 1 through 15. providing evidence that a comparative measurement to indicate depth of weld penetration on a percentage basis by ultrasonic examination is reliable.

Helium Leak Testing

Qualification of the helium leak examination was accomplished by testing 25 qualification test capsules and comparing the results of destructive and nondestructive tests. Leak testing was performed in accordance with Section V. Article 10:T-1060 of the American Society of Mechanical Engineers (ASME). The tracer gas (helium) was placed in the test capsules, at the time of welding on the closure cap, by use of a helium saturated sintered disc. Testing was performed by the vacuum encapsulator method. A permeation type calibration leak standard with a leak rate of $5.1 \times$ $10^{-8} \mathrm{Std}, \mathrm{cc} / \mathrm{sec}$. was used. Presence of the trace gas in the capsules was verified after nondestructive testing by drilling holes through the capsule cap to release the trace gas for detection by the "sniffer" probe. 
8

The test capsules and the powdered metal disc are shown in Figures 16 and 17.

DESTRUCTIVE TESTING

Rupture Tests

The rupture tests provided depth-of-penetration data which was correlated with the welding parameters, ultrasonic examination data, and macroexamination data as shown in Figures 1 through 15 . The welding amperage was reduced $10,20,30,40$ and 50 percent to produce the variation in penetration. The welded capsules were ultrasonically examined prior to rupture testing. After the rupture tests were completed, the weld area was sectioned and etched and a macro-examination performed. From these data, the welding parameters were established with which to produce a weld depth-of-penetration equal to 100 percent of the tube wall thickness, (sometimes referred to as a 1-T Teak path), thereby qualifying the welding procedure.

Metallography

The metallographic examination of the weld area was used to determine the depth-of-weld penetration. Comparison of the macro-section of each weld with the ultrasonic examination record correlated favorably for depth-of-penetration on a percentage basis.

\section{ACCEPTANCE CRITERIA}

WELDING PROCEDURE DEVELOPMENT

Joint Design

Buildup of internal pressure during the welding operation must be relieved if a sound weld is to be achieved. The initial design of the top cover incorporated a $3 / 32$ inch diameter hole, drilled in the center, through which this pressure was released. This hole was then used to place the helium trace gas inside the capsule for nondestructive examination and subsequently welded shut by a separate welding procedure. Drilling of This hole required an additional machine shop operation which in turn required another inspection operation.

Welding this purge hole closed required an additional welding operation and an additional welding fixture, torch, etc. Micro-cracks were occurring at the extremity or back side of the weld nugget in the purge hole welds on the cesium chloride (type 316-L stainless stee1) capsule. Figure 18 shows the joint design which was developed to overcome the micro-cracking problem and eliminate the additional machining, inspection, 
and welding operations.

\section{Helium Storage Disc}

With the relocation of the pressure relief hole, a new method for placement of the trace gas into the capsule was needed. As a result, the powdered metal, compacted and sintered disc, shown in Figure 17 was developed. The porous metal disc is simply saturated with the trace gas (helium) and placed in the capsule just prior to welding of the top cover to the capsule tube.

\section{Strontium Fluoride Baffle}

The placement of a barrier or baffle in the strontium fluoride (Hastelloy C-276) inner capsule, preventing the $\mathrm{SrF}_{2}$ powder from contaminating the back side of the weld joint, has permitted welding in the horizontal position, manufacturing the helium disc to the appropriate dimensions has permitted the use of the disc as a baffle in addition to its primary function, thereby el iminating the need for a separate baffle component. Location of the helium storage disc used as a baffle in the strontium fluoride inner capsule, is shown in Figure 19.

\section{Welding Parameters}

The welding parameters, including weld current, arc voltage, electrode geometry, welding speed, shielding gas flow-rate, etc., were developed coincident with the destructive testing of the full size waste storage capsules. These parameters are controlled by a pre-cut programmer card which is placed in the automatic welding machine control system to perform each weld function. The original "master" card is made of a plastic material and incorporates all the welding parameters in printed sequence on the face of the card. The "operating" card is made from brass sheet stock and is an exact copy of the master card except that in lieu of the printed information it has only a "CODE" number which is called out in the welding procedure. The plastic or "master" card will be retained in the permanent files and will be used only in the event of a misplaced or damaged "operating" card. It may also be used as a calibration standard at any time there is a need to check the operating card for wear or alteration. These welding parameter control cards are included in and become a part of the written welding procedure. Card selection for a given weld function is made by reference to a code number stamped on the metal control card.

The welding parameters were selected on the basis of depth-of-penetration to rupture ratio as shown in Figures 1 through 15 ; for example, information gained during these tests show that the depth-of-weld penetration at which rupture may occur in either the tubing or the weld joint is at approximately 60 percent of the tube wall thickness. Tests 1 
and 2 (Figures 1 and 2) show that failure occurred in the weld when penetration was 50 and 60 percent. Tests 3 and 4 (Figures 3 and 4) show that with 90 and 100 percent penetration, failure occurred in the tube wall. Test number 5 (Figure 5) weld parameters were chosen to provide a 65 percent weld penetration. As a result, failure occurred in the tube wal7. It may be noted in tests 3 and 4 that the percent penetration was considerably higher than the 50 to 60 percent failure threshold; however, it may also be noted that the rupture pressure was somewhat higher in tests 3 and 4 . The 10,950 psi rupture pressure, at which failure in the tube wall in test 5 occurred, would further indicate that structural failure of the strontium fluoride capsule (Hastelloy $\mathrm{C}-276$ ), due to an increase in internal pressure, will occur in the tubing material when weld penetration is greater than 60 percent of tube wall thickness.

Tests $6,7,8$ and 15 depict the depth of weld penetration to rupture ratio in the cesium chloride (316-L SS) inner capsule. Comparison of the welding current values will show that, although weld current was varied from 120 amperes (Figure 8) down to 50 amperes (Figure 15), to produce depth-of-penetration from 100 percent to 50 percent, failure occurred in the tube material in all cases.

Tests 9, 10 and 11 show the depth-of-penetration rupture ratio in the strontium fluoride (Hastelloy C-276) outer capsules. Again, comparison of these test data will show that a variation of weld current from 150 down to 50 amperes and a subsequent penetration of 100 down to 75 percent of wall thickness resulted in rupture failure in the tubing material.

Tests 12,13 and 14 show once again, failure occurred in the tubing material even though weld current was varied from 140 down to 60 amperes and depth-of-penetration varied from 100 down to 55 percent of tube wall thickness. As a result of these test data, the parameters for welding the end caps to the waste storage capsules were selected which would produce weld penetration equal to 100 percent of tube wal1 thickness.

NONDESTRUCTIVE EXAMINATION PROCEDURE DEVELOPMENT

Hel ium Mass Spectrometer

Assurance of a leak tight container is mandatory in the waste storage encapsulation program. To provide this assurance, the helium leak examination was qualified and will be used to inspect the inner capsules. The acceptance criteria used during these tests was determined by results of 25 qualification tests. There was no detectable leakage in excess of the calibrated leak $\left(5.1 \times 10^{-8} \mathrm{std} . \mathrm{cc} / \mathrm{sec}.\right)$. These tests indicate that the acceptance criteria for helium leak examination should be established as an integrated leak rate with an allowable specified value not 
to exceed $5.1 \times 10^{-8} \mathrm{std} . \mathrm{cc} / \mathrm{sec}$. of helium. Since the physical conditions under which the test equipment will be operating in-cell will be different from the conditions used in these tests, $i . e$. vacuum lines in excess of 25 feet opposed to 18 inches, filters in the vacuum line, use of cooling water to control temperature of the test chamber, etc. , final determination of acceptance criteria will be established under $i n=c e l 1$ operating conditions. Tests are currently being conducted at Battelle-Northwest Laboratory (BNW) using a mock-up of the in-cell conditions for this purpose. As a result of these tests, helium leak examination operating procedures will be developed and written and the acceptance criteria with which to govern the leak integrity of the waste storage capsules will be established.

\section{UT trasonic}

Production capsule welds are expected to produce penetration of the capto-tube joint, equivalent to 100 percent of the capsule wall thickness. Qualification test data indicates that 100 percent weld penetration will be obtained; however, it should be obvious that certain conditions, i.e., improper assembly, poor fit-up, inadequate cleaning, contaminated electrode, electrical component drift or failure, or a combination of any of these variables, may be of sufficient magni tude to prevent the weld penetration from being 100 percent. In view of this possibility, reasonable criteria was established for the acceptance or rejection of the capsule welds by ultrasonic examination. To develop this criteria, the full size capsule destructive tests, as shown in Figures 1 through 15, were conducted to determine the effect of incomplete weld penetration on capsule integrity.

As has been shown by these tests. structural integrity of the capsule, equal to its tube material strength, is assured when well penetration is equal to or exceeds 60 percent of tube wall thickness. The comparative test data provided by the burst-rupture tests has shown that a reliable measurement of depth-of-weld penetration can be made by ultrasonic examination on a percentage basis. Results of the ultrasonic examination, destructive tests, and metallographic examination have been used to determine a reasonable amount of deviation from 100 percent penetration. The minimum acceptable depth-of-weld penetration is, therefore, established as 75 percent of tube wall thickness. This criteria shall be used for governing the acceptance or rejection of capsule welds by ultrasonic examination.

\section{NONDESTRUCTIVE EXAMINATION}

\section{HELIUM LEAK MASS SPECTROMETER}

Procedure Development

The operating procedure for the helium leak examination will be developed 
and written based on the conclusions of the tests being conducted by Battelle-Northwest Laboratories.

ULTRASONIC

Procedure Development

Development of the operating procedures for ultrasonic examination of the capsule welds was conducted concurrent with development of the acceptance criteria and was based on the results of the rupture test data, metal10graphic examination, and ultrasonic examination records as depicted in Figures 1 through 15. The essential elements which control the procedure operating parameters are shown in Figures 20, 21, 22, and 23.

\section{FLORESCENT PENETRANT EXAMINATION}

Florescent penetrant examination will be applied to the cold end cap welds prior to placement of the capsules into the hot cells for loading. This examination will be performed by the shop doing the cold end cap welding. The examination will be performed in accordance with an approved written procedure.

\section{CALIBRATION STANDARDS}

\section{WELDING EQUIPMENT}

\section{Pulsed Current Power Supply}

A comprehensive calibration was performed on each pulsed current power supply before conducting the final welding procedure development tests. A calibration procedure was written at this time which has been included in the facilities operating manual and will be used for periodic calibration of the pulsed current welding power supply.

\section{In-Cell Welding Fixtures}

The maximum torque permitted at the collet chuck on the in-cell welding fixtures is 15 inches per pound. A "DuMMy" capsule with a "hex" nut welded on the cap has been provided and will be used in conjunction with a torque meter to periodically test these fixtures.

\section{Motor Calibration}

Since regulation of the welding speed is dependent upon the constant speed of the DC drive motor, calibration of the motor is checked as a part of the welding procedure prior to welding. This is made possible by use of a prepunched "MOTOR CALIBRATION CARD" which is placed in the welding programmer. 


\section{NONDESTRUCTIVE EXAMINATION EQUIPMENT}

\section{HELIUM MASS SPECTROMETER}

Sensitivity of the helium leak equipment is assured by the use of a calibrated leak standard with a leak rate of $5.1 \times 10^{-8} \mathrm{Std}$. $\mathrm{cc} / \mathrm{sec}$.

\section{ULTRASONIC EXAMINATION}

Calibration of the $X-Y$ scanner and the in-cell $C_{-}-s c a n$ equipment is maintained by the use of flat-bottom drilled-hole standards. The operating procedure requires that the equipment be calibrated to these standards before and after each test. A welded cap standard, having a known 75 percent depth-of-penetration weld, is also provided at each station and is to be scanned for comparison with the scan of the storage capsule.

\section{QUALITY CONTROL}

\section{WELDING}

A chart trace of amperage, voltage, and welding time is automatically recorded of each storage capsule weld. The serial number of the storage capsule and identification of the welding machine and operator will be entered on the chart record. This record will be placed in the capsule packet as part of the permanent record file.

\section{NONDESTRUCTIVE EXAMINATION}

A recorded trace or "image" of both the C-scan (in-cell) and the $X-Y$ scan (cold-end cap) examinations of the capsule welds will be retained for each storage capsule. The serial number of the capsule, the serial number of the transducer used and a record of the calibration (flat bottom hole) standard and 75 percent standard scan will be placed in the capsule file and be retained as a permanent record.

\section{SUMMARY}

The welding and nondestructive examination development work reported herein was conducted essentially as outlined in the letter of August 26, 1972 from J.C. Wormeli to D.D. Wodrich, "Clarification and Explanation of Work Efforts." Specifically, the items referred to were as follows:

1. Outline of test work for welding and qualification of waste storage capsules. 
2. Development of specification criteria for acceptance of capsule welds.

3. Nondestructive examination activities for capsule work.

Qualification testing of capsule material, development of capsule welds, and nondestructive examination procedures have been accomplished prior to welding of capsules in the new encapsulation facility.

Successfur completion of these tests has qualified the material, welding procedures, and nondestructive examination techniques. Permanent records will be maintained of all test data and physical evidence test specimens, of all phases of this development work.

Final adjustment, i.e., minor changes in amperage, voltage etc., due to characteristics peculiar to hot-cell operation which could not be forseen, of the capsule welding and nondestructive examination procedures will be made during the cold-run facility shake-down and first tracer hotcell check-out operation. Formal approval of those procedures will be made after satisfactory performance of the capsule welding and nondestructive examination operations using these procedures.

\section{REFERENCES}

- ARH-3027: Development Procedure for Welding of Waste Storage Capsules.

- ARH-3028: Cold End Cap Welding Development Procedure Using the Shop Welding Fixture and Model V-300-P-AUTO-ARC Welding Machine.

SUPPLEMENT TO

Section IV, b., of Development Procedure ARH-3027 for Welding of Was te Storage Capsules, Aug., 1973.

- ARH-3029: Development Procedure for Ultrasonic Examination of the Waste Storage Capsule Bottom Cap Welds Using the Automation Industries No. U.S.-454 Lab-Scanning System.

- ARH-3030: Development Procedure for Ultrasonic Examination of the Waste Storage Capsule Top Cap Welds Using the In-Cell Scanning System. 


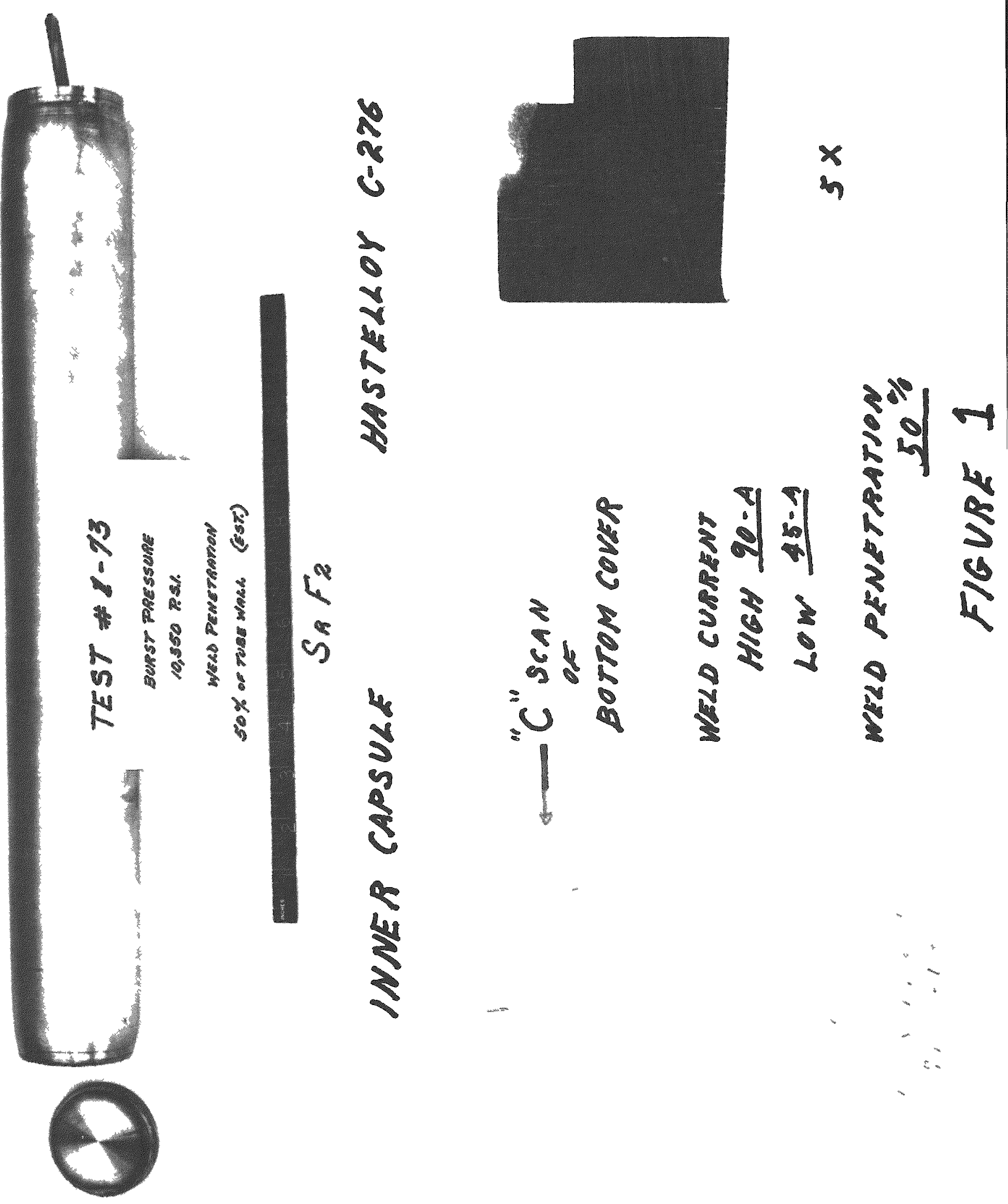




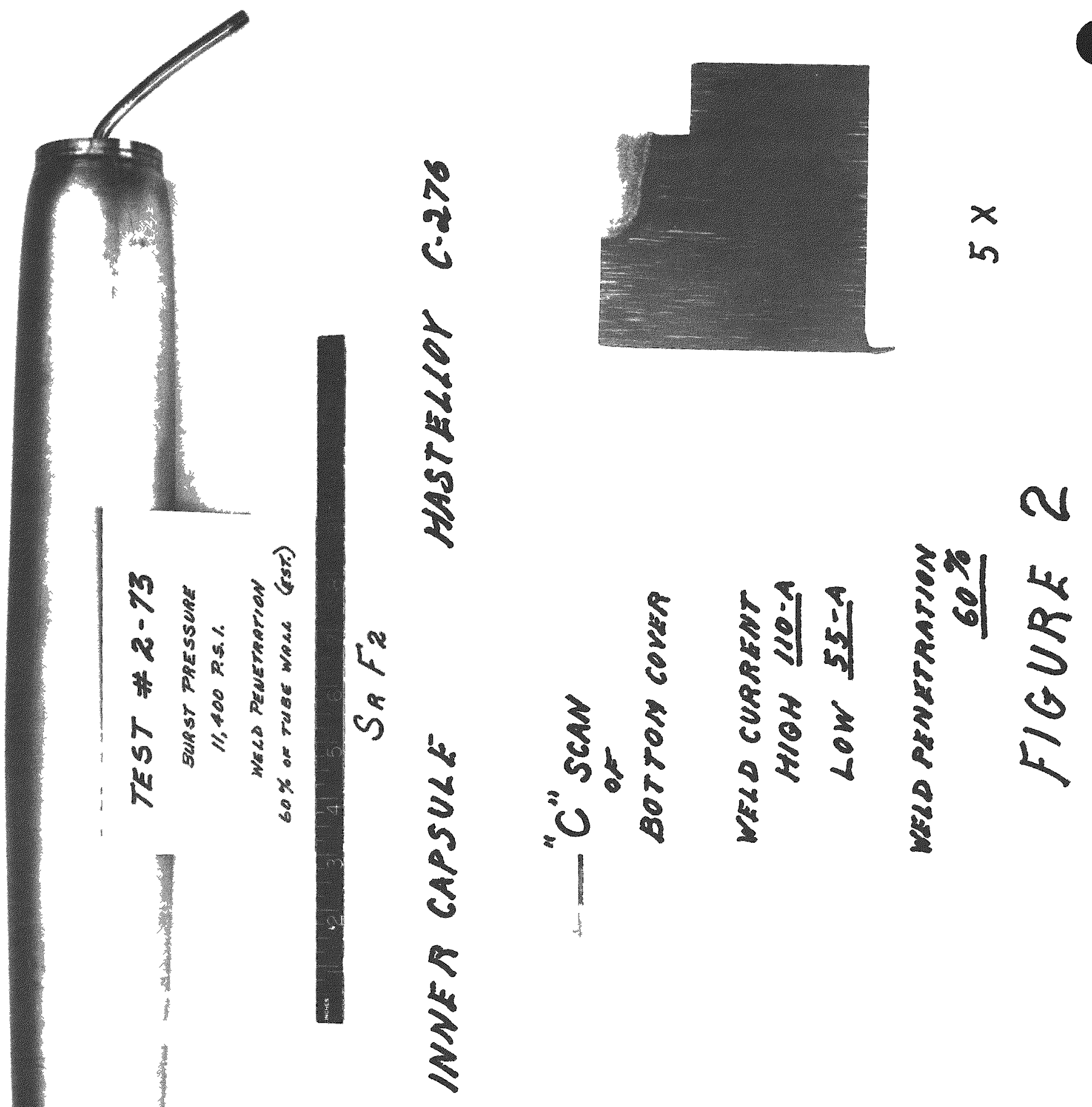



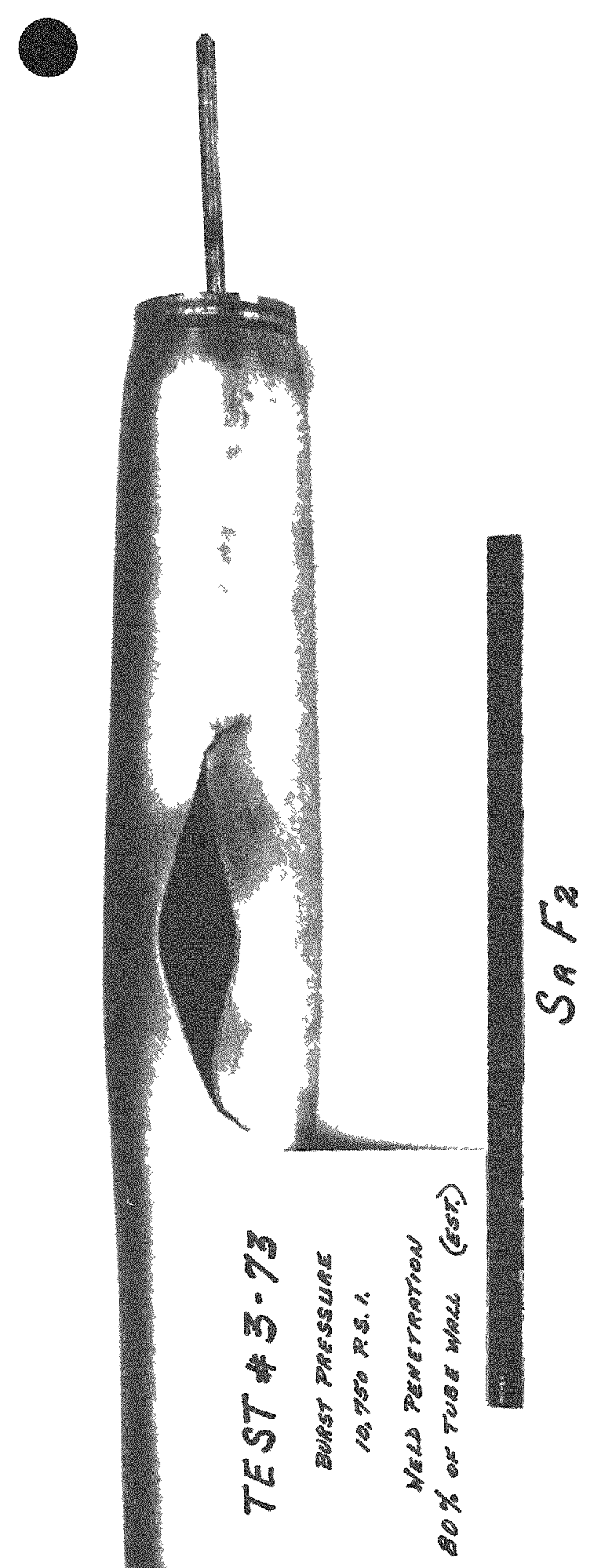

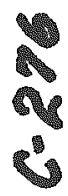

1
2
2
2

3

2

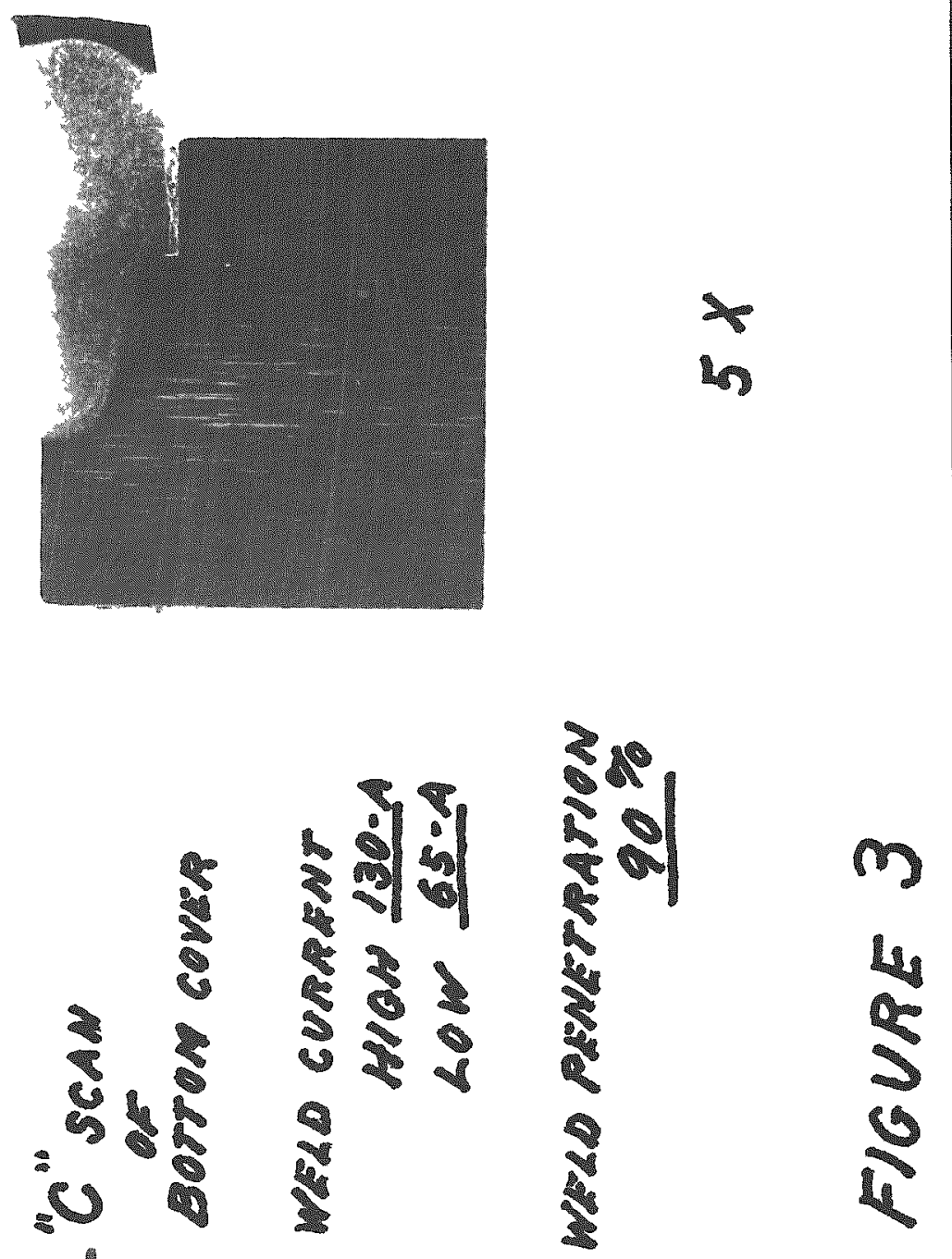



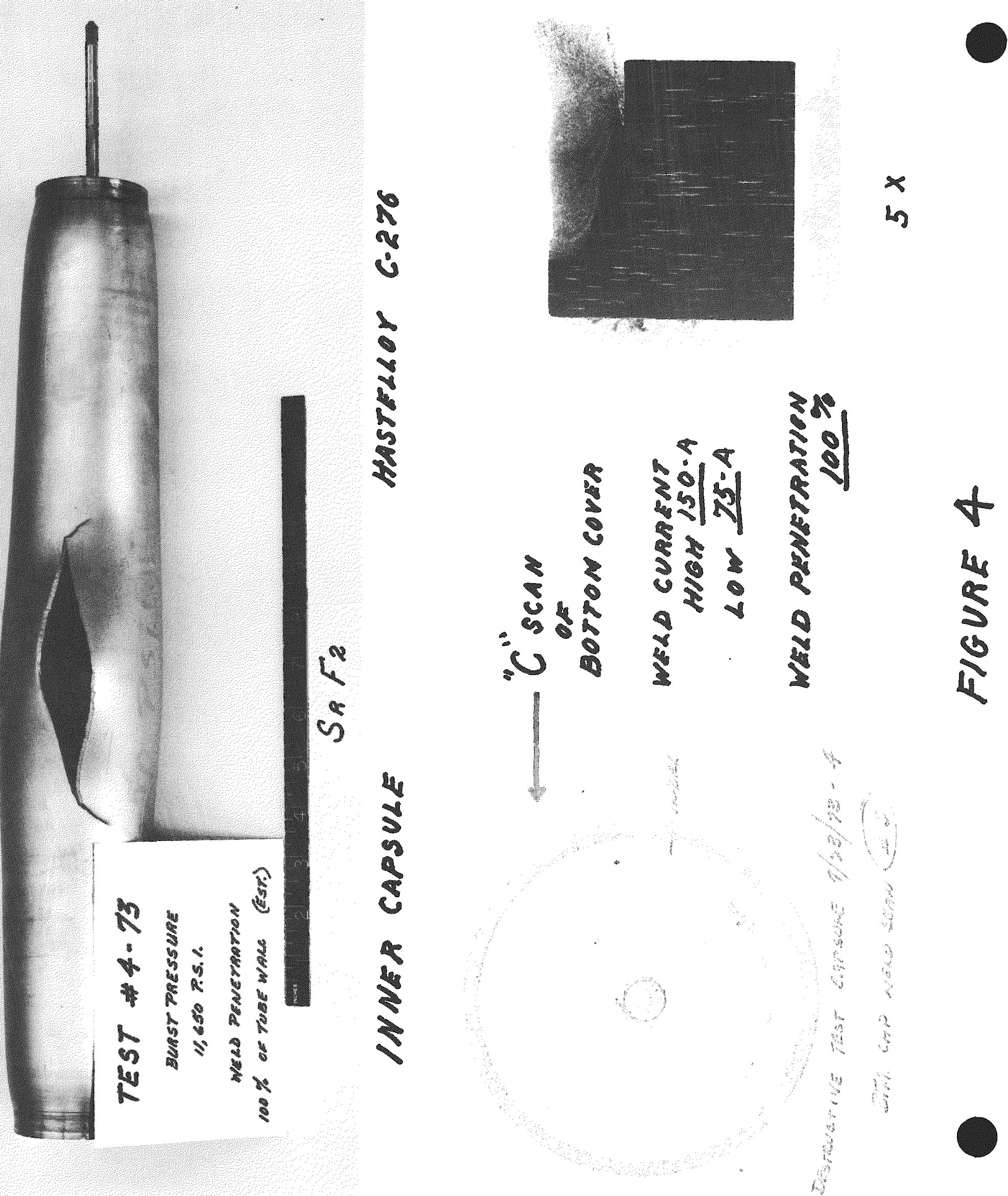


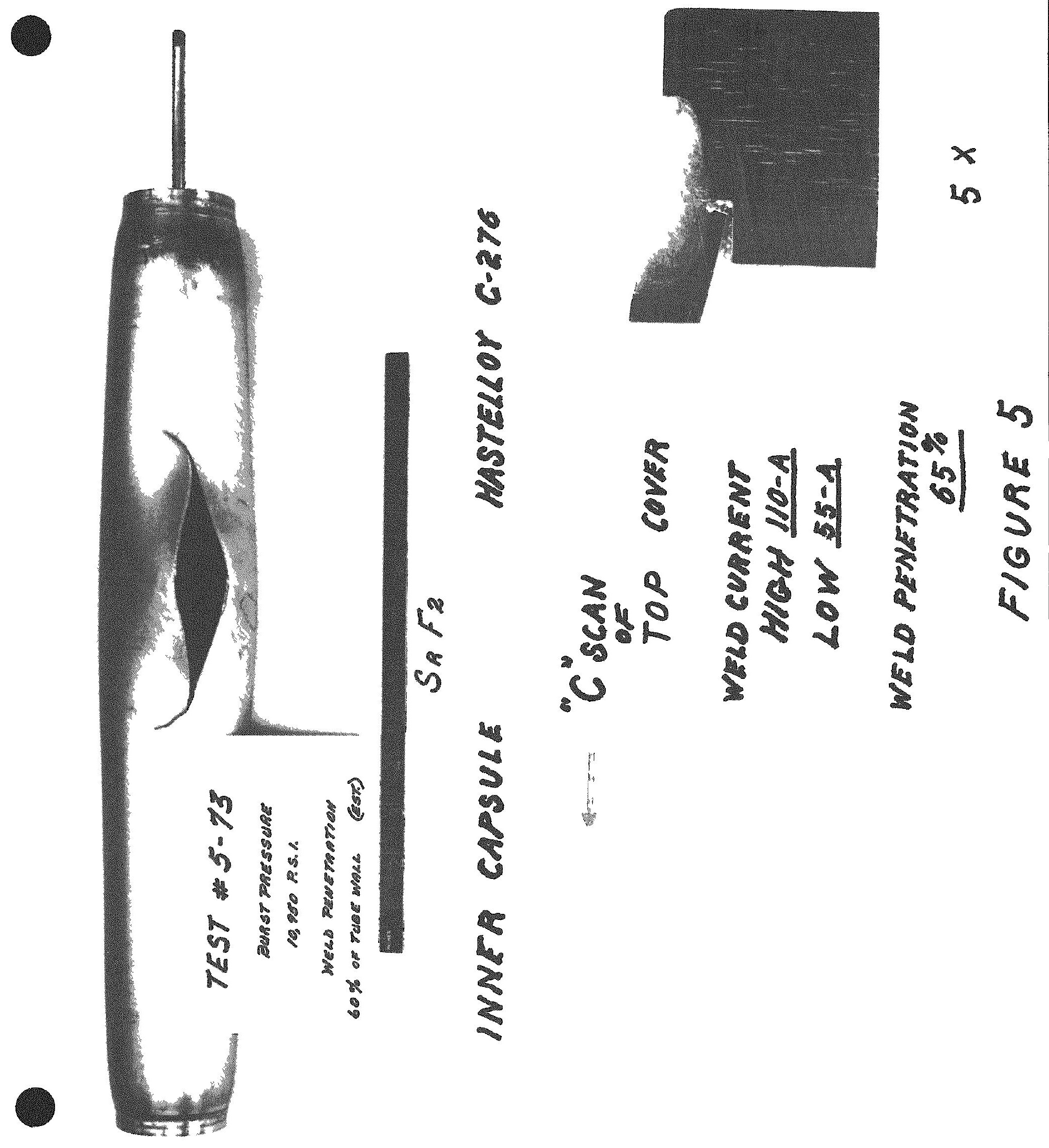




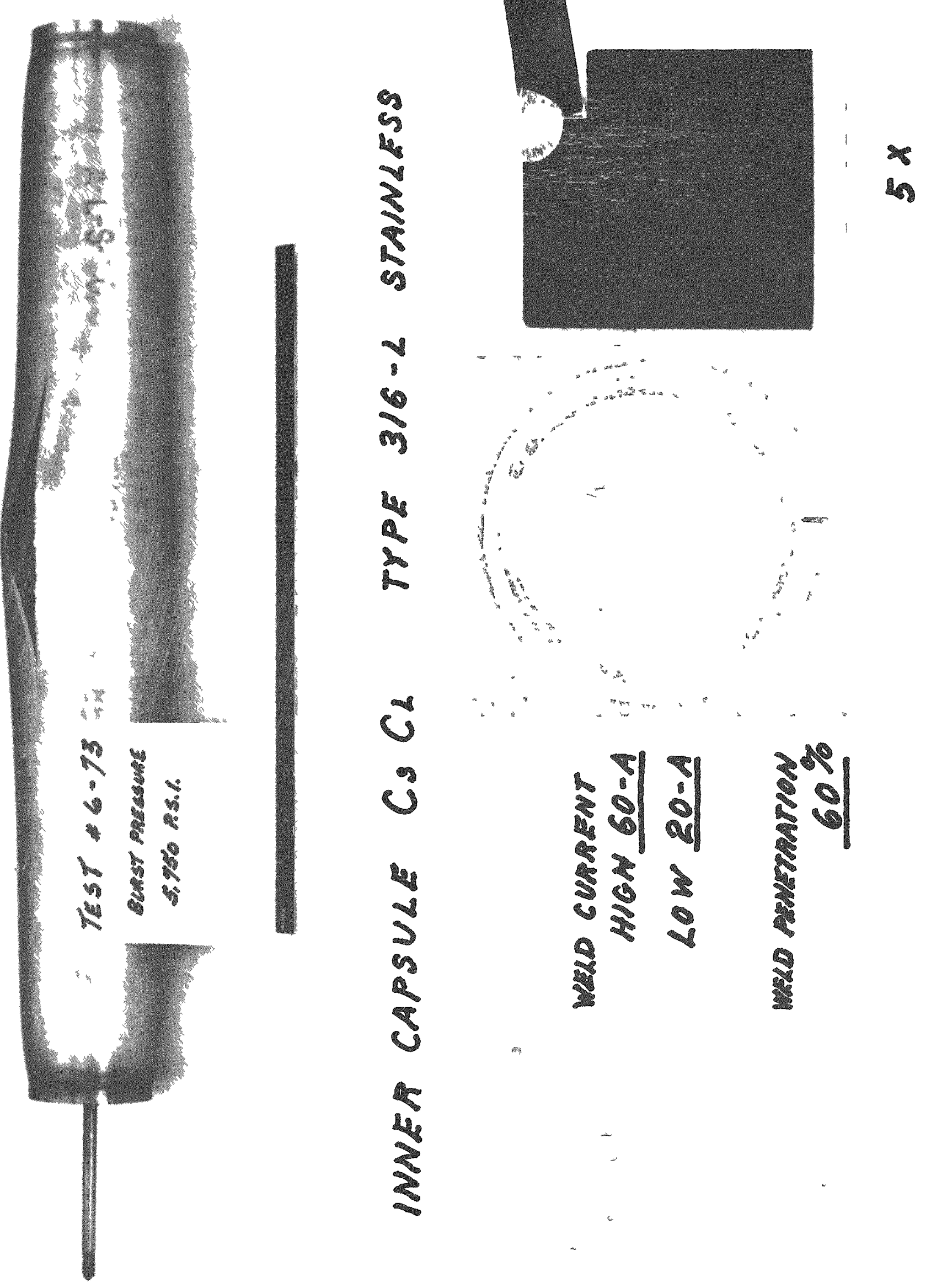



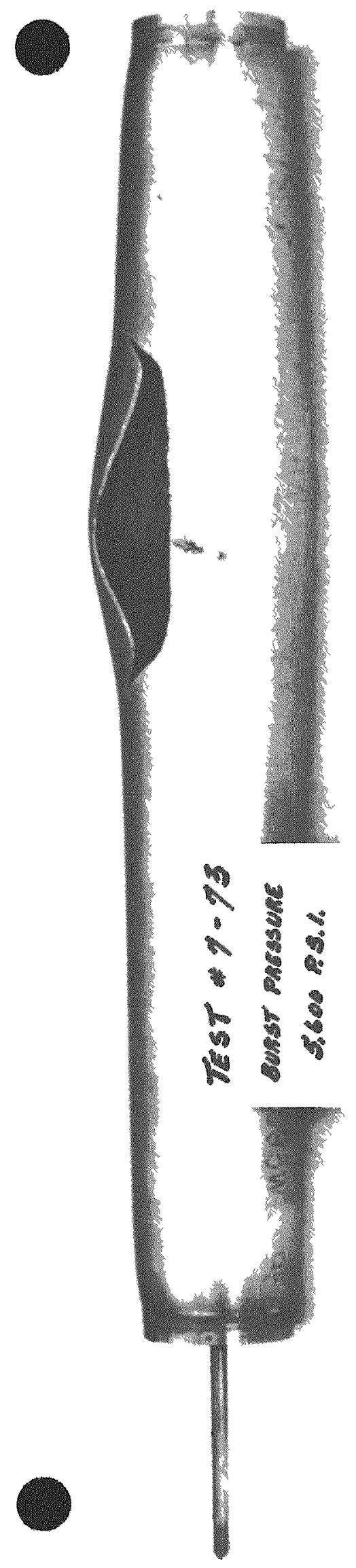

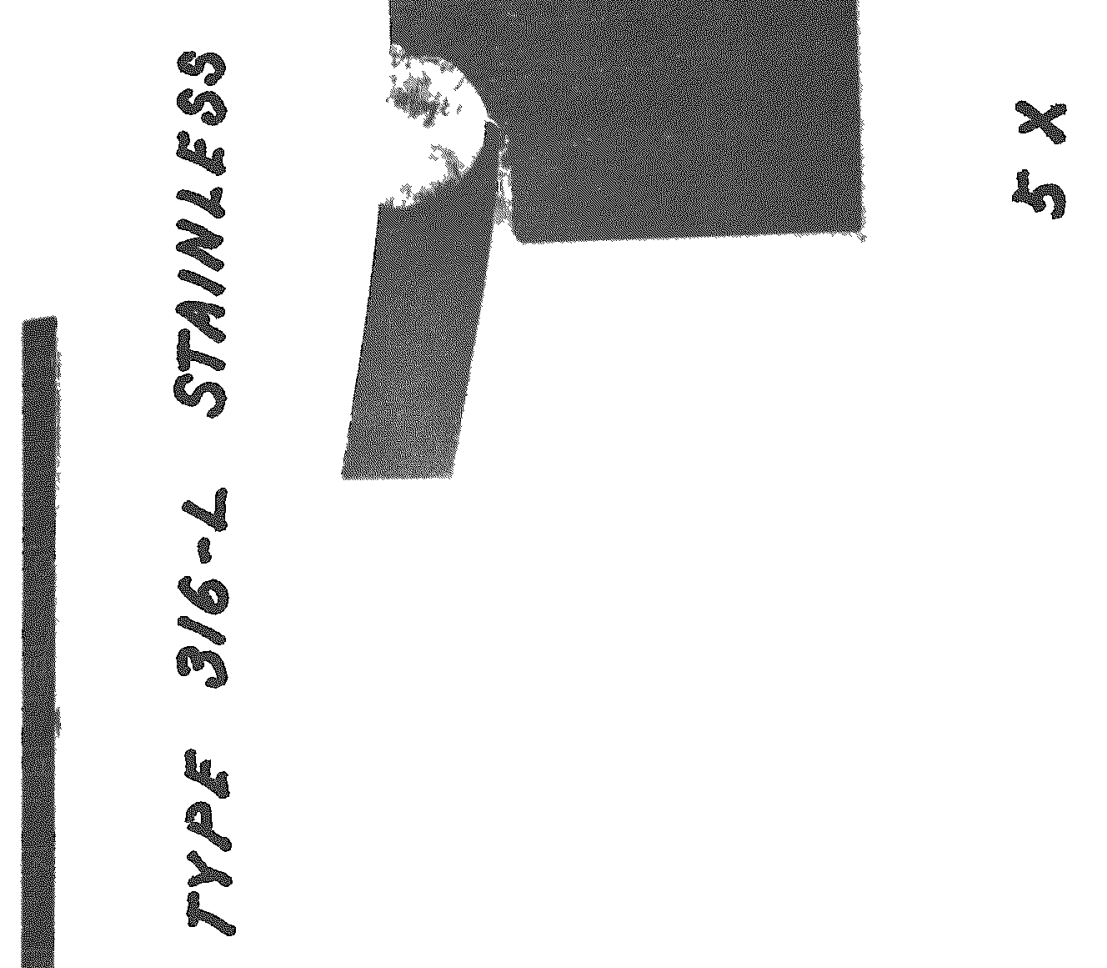

1

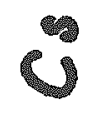

4
4
4
4

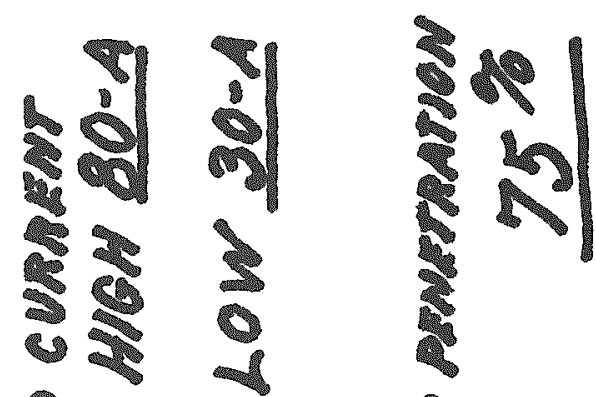

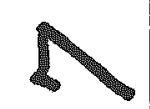

$0^{\circ}$ \&

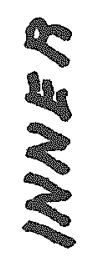




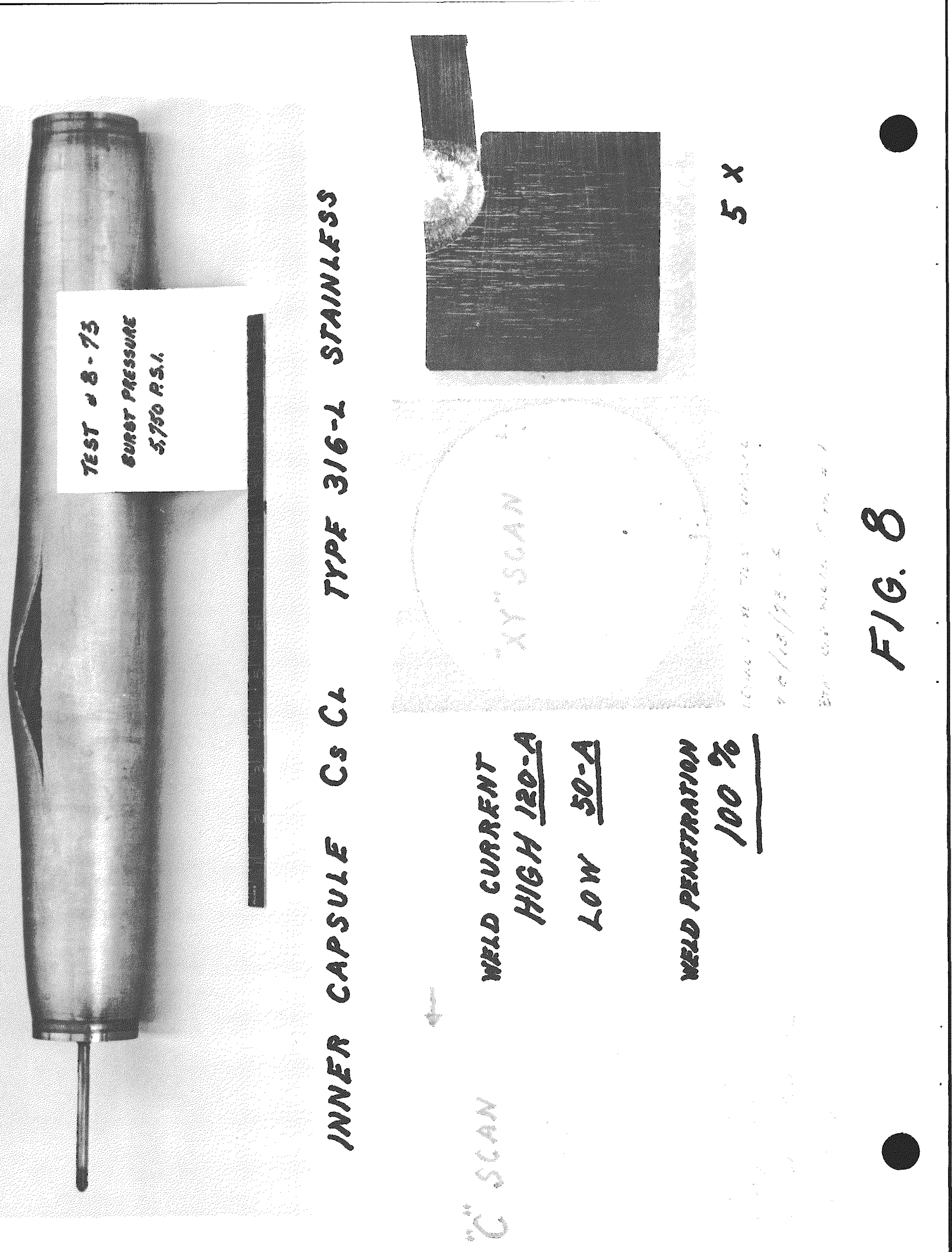




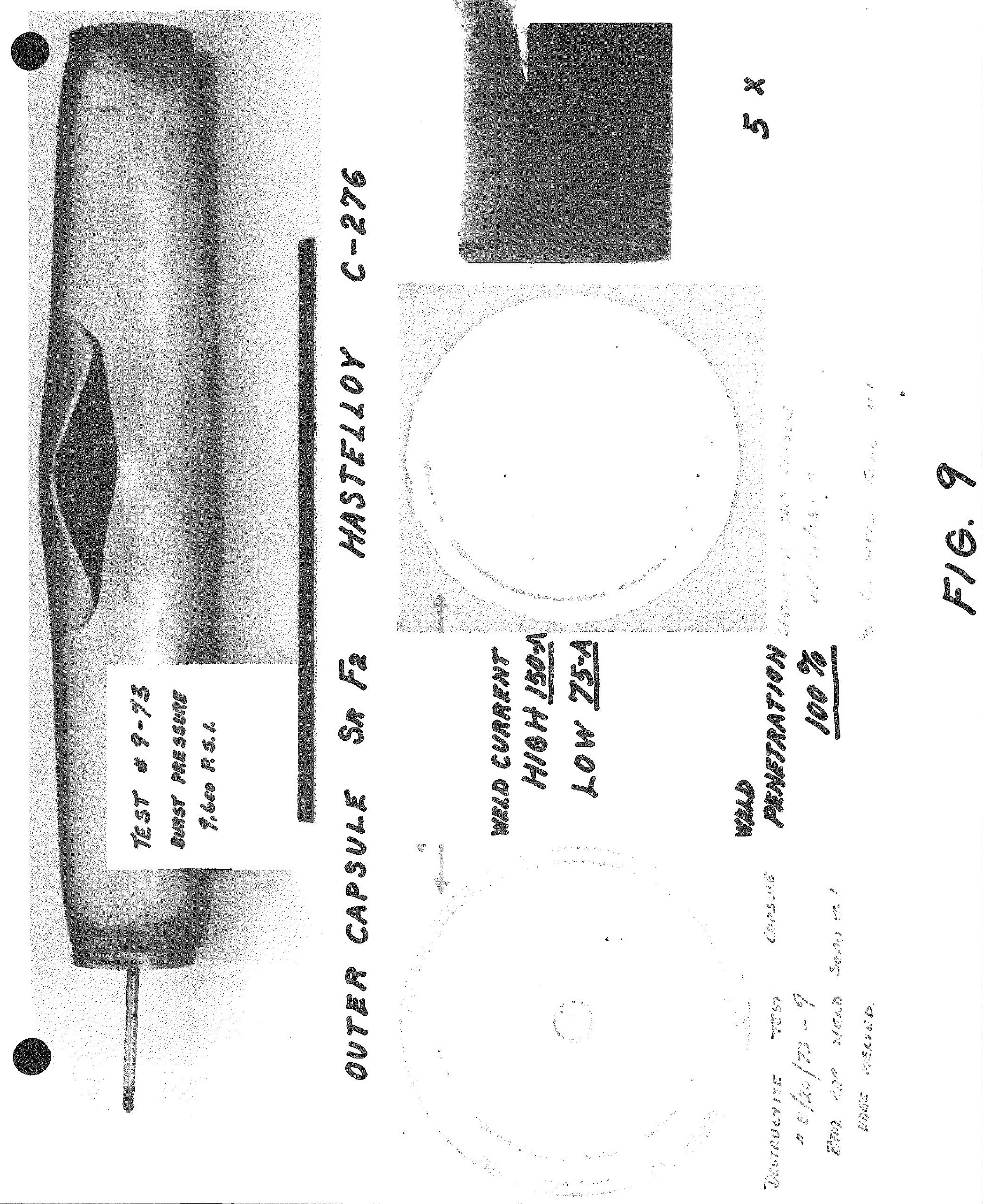



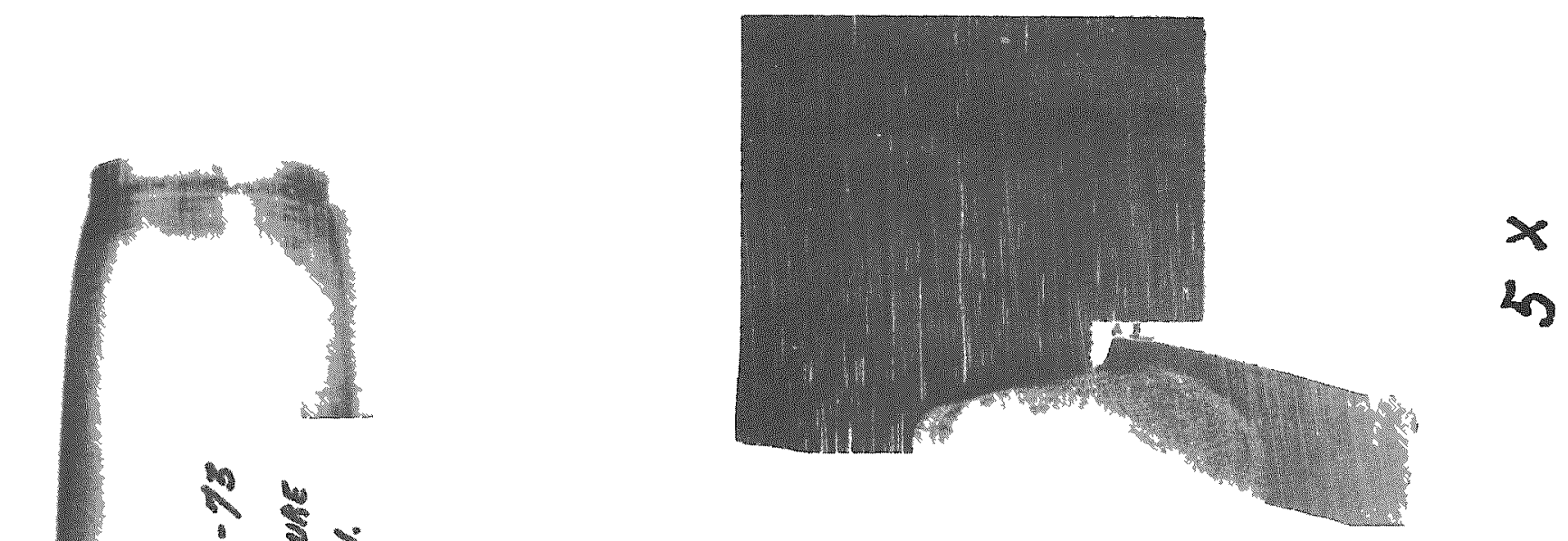

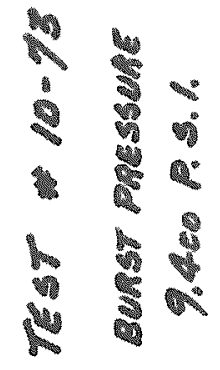
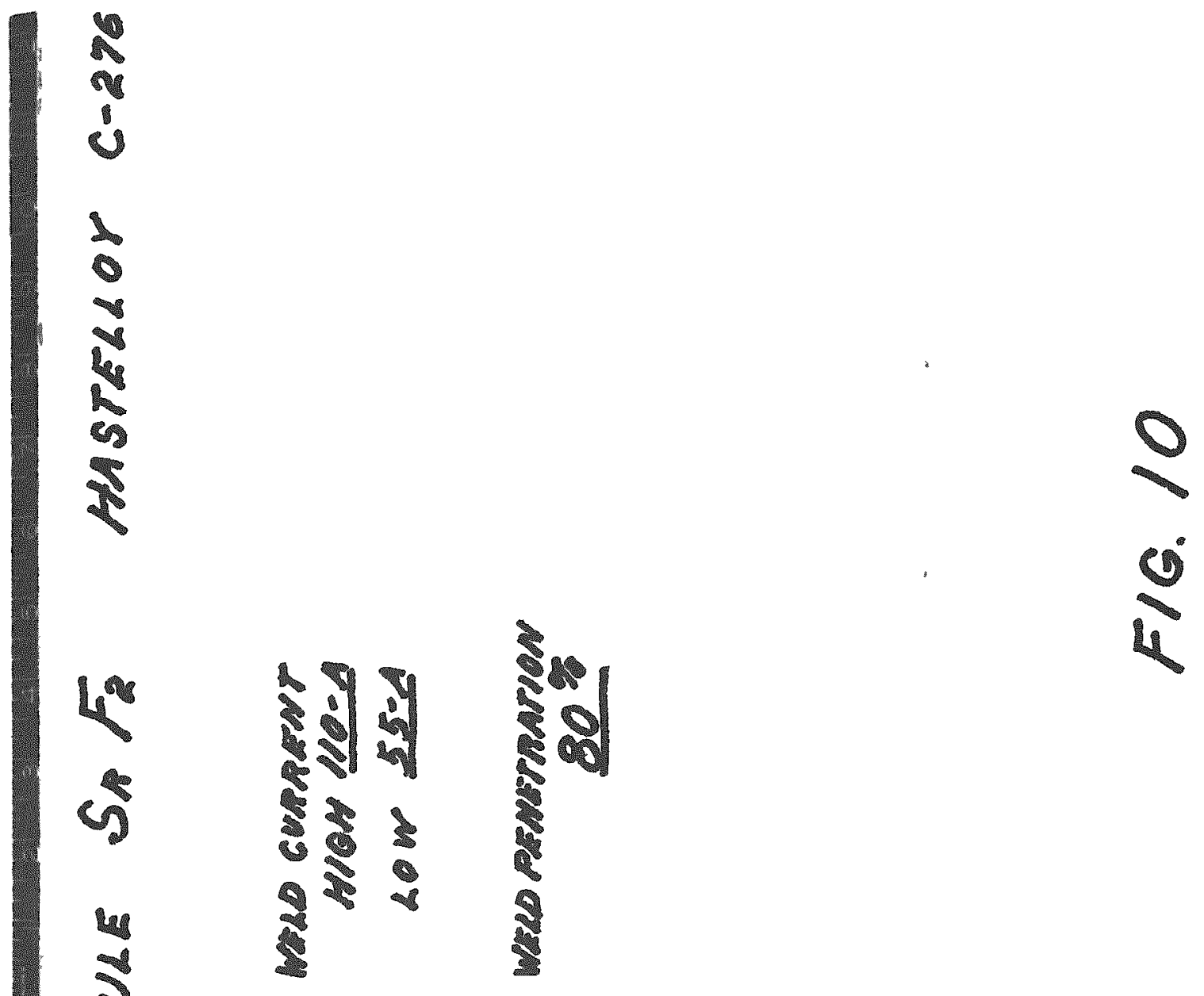

4

10

3

4

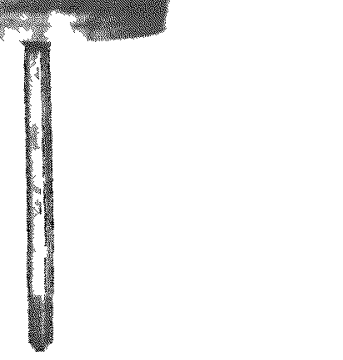



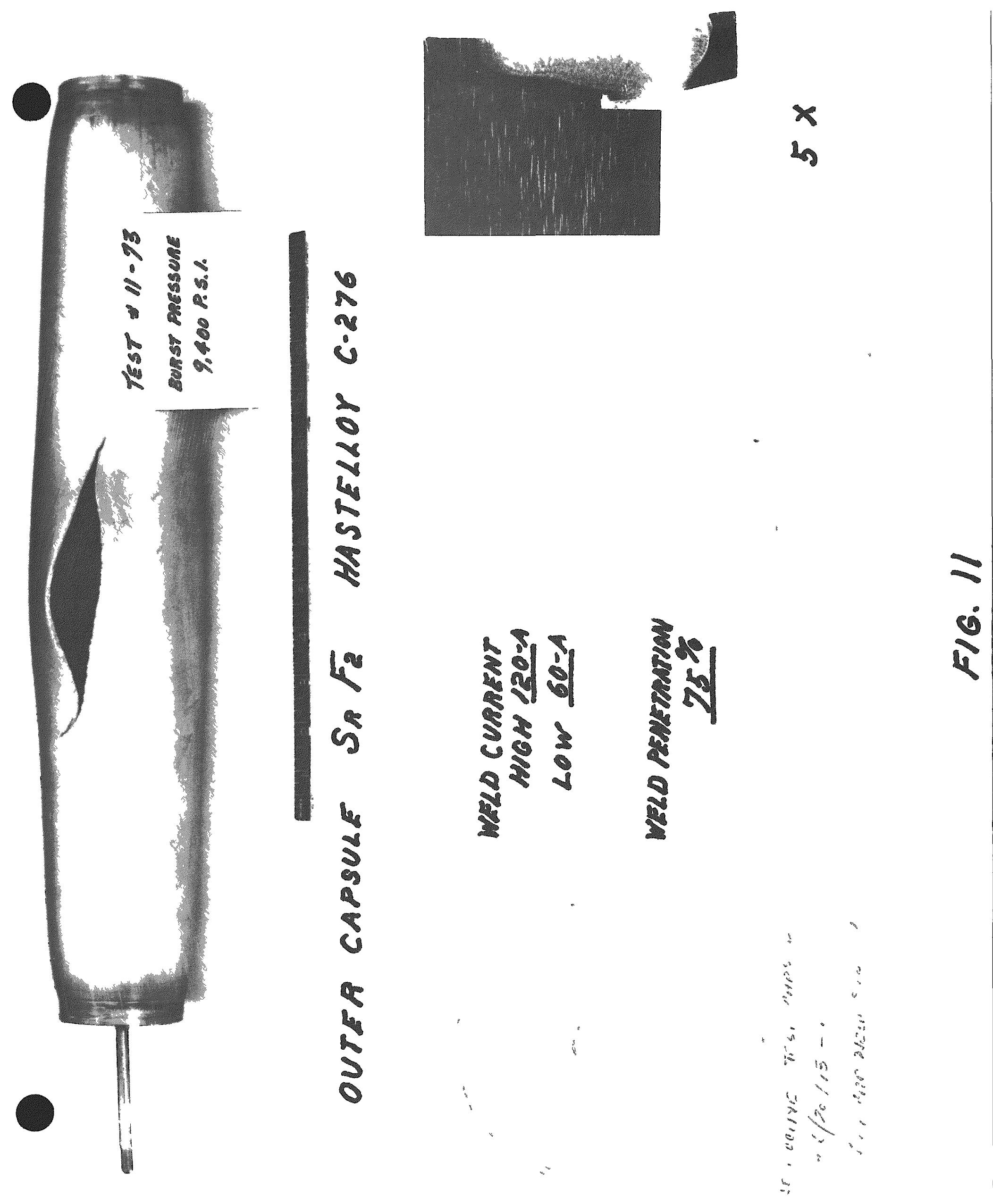

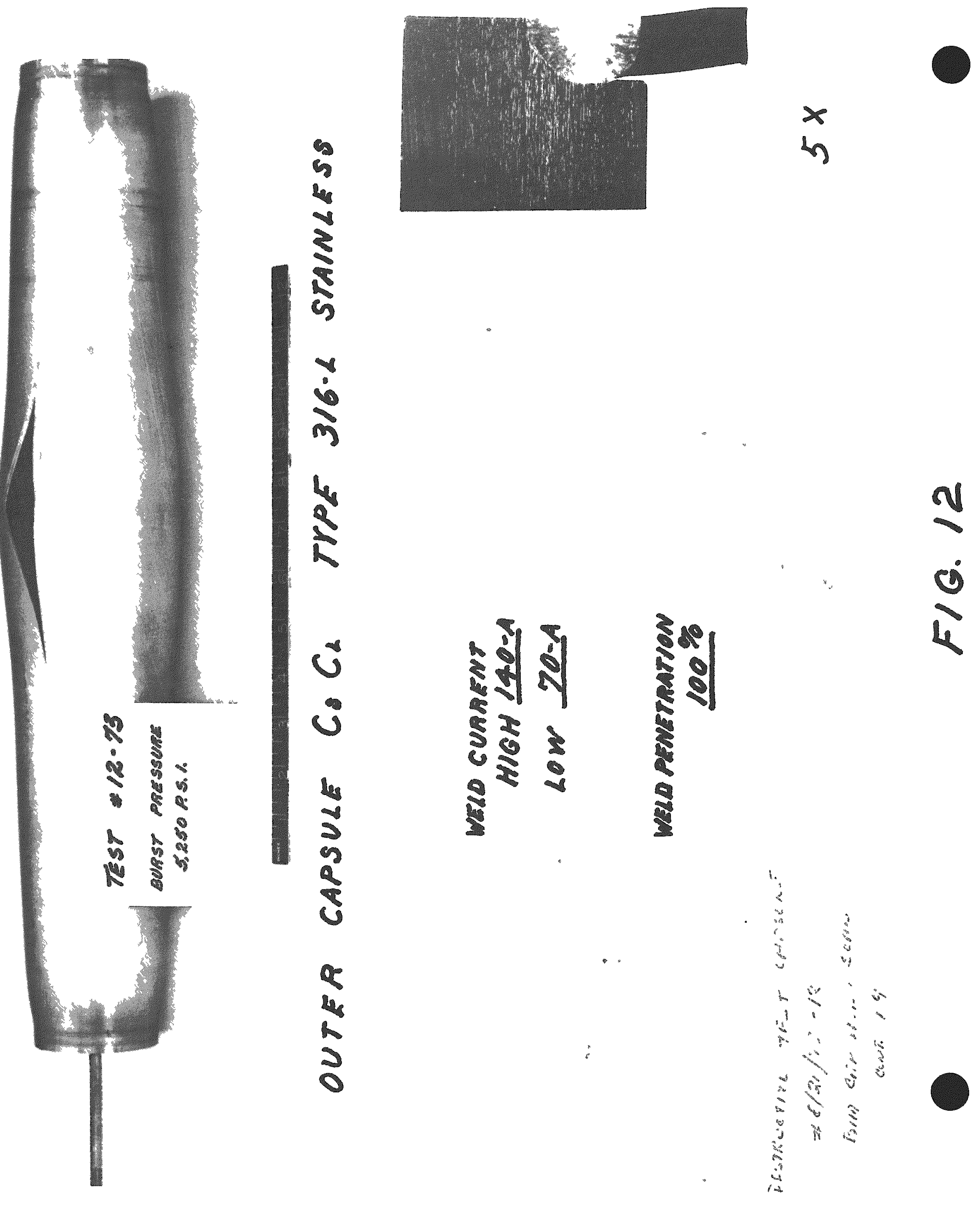

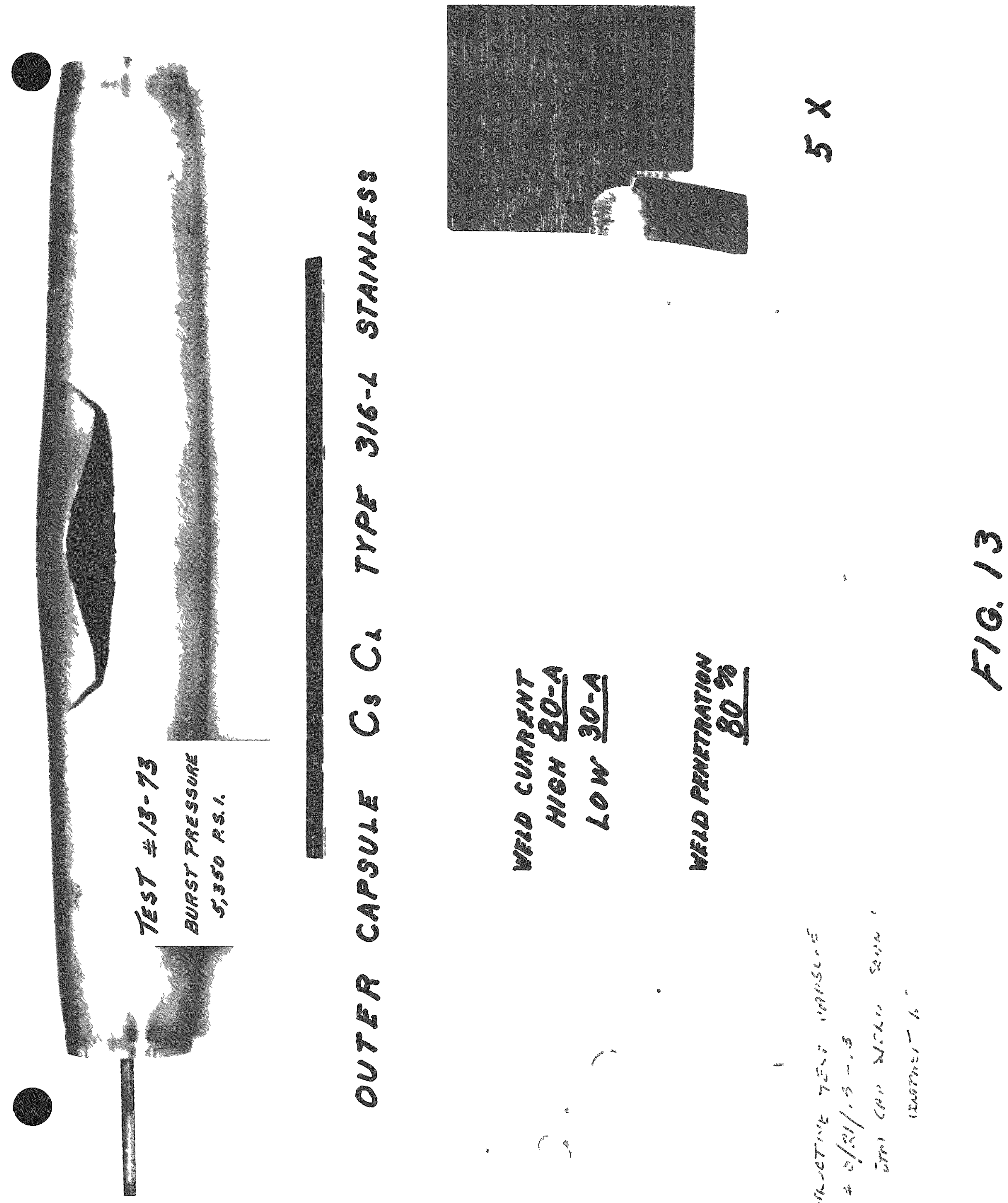


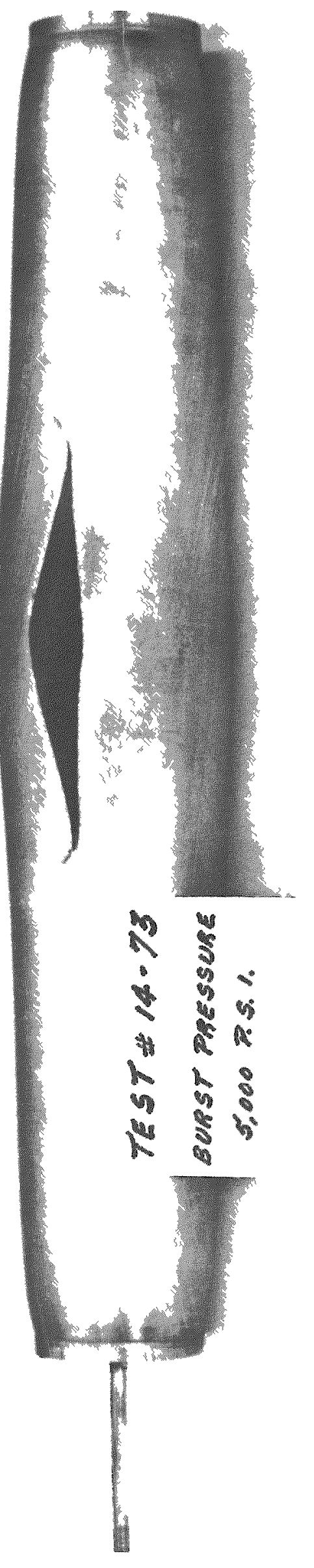

3
5
5
5

6

2

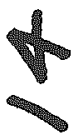

3

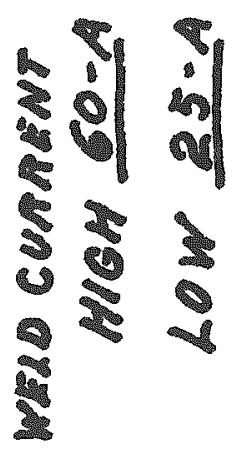

21
-4
5

S

s

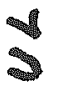

9

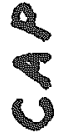

1

4

5 

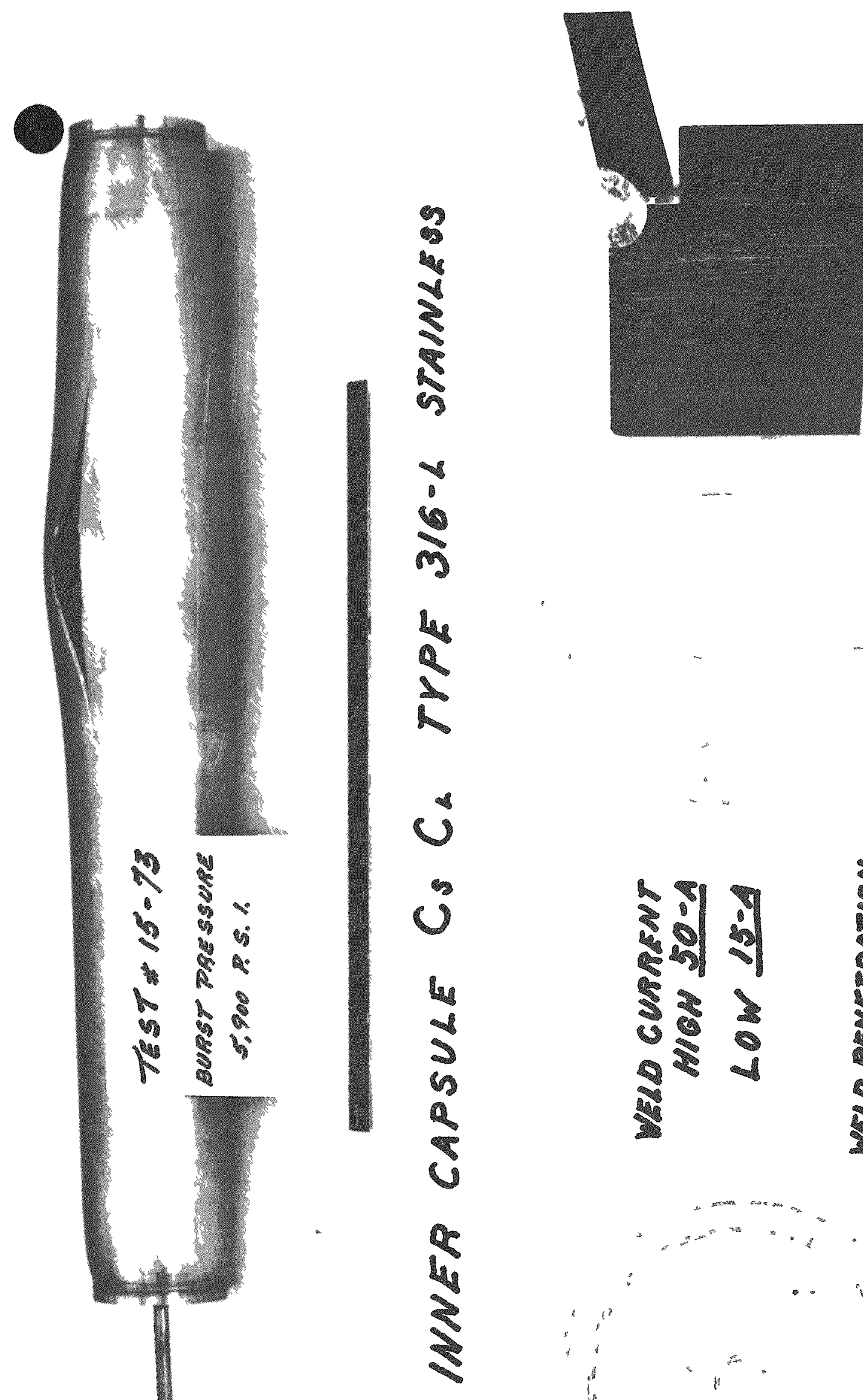

$x$
6

$b$

4
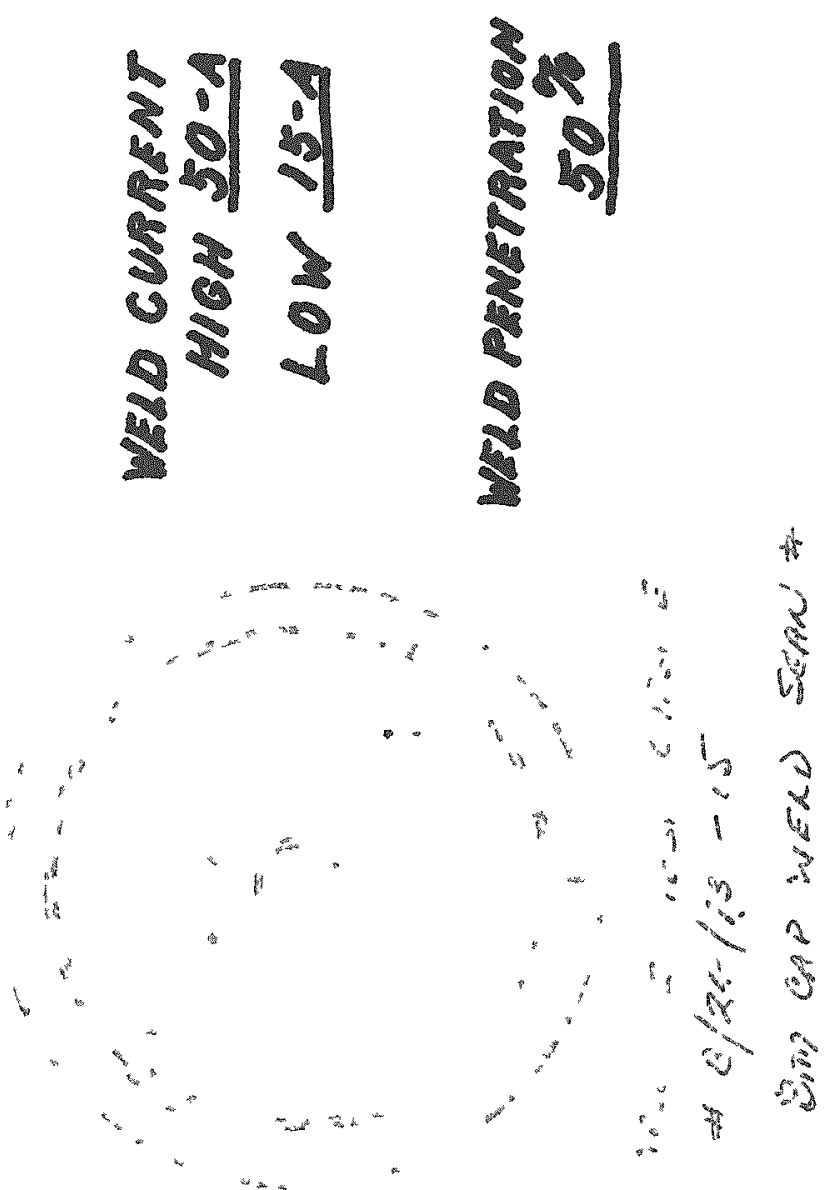


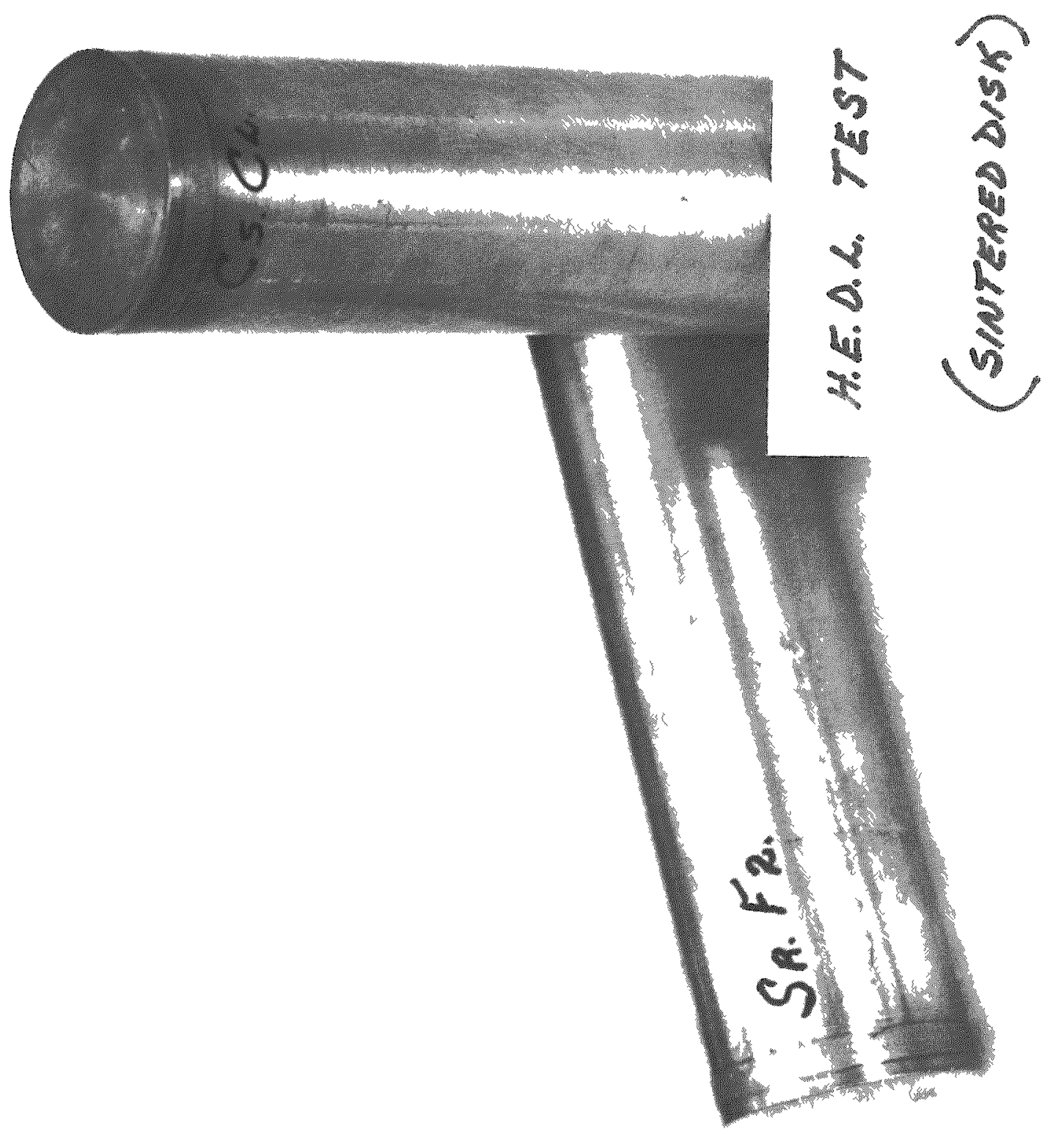

6

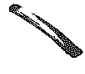

$0^{\circ}$ ऐ 

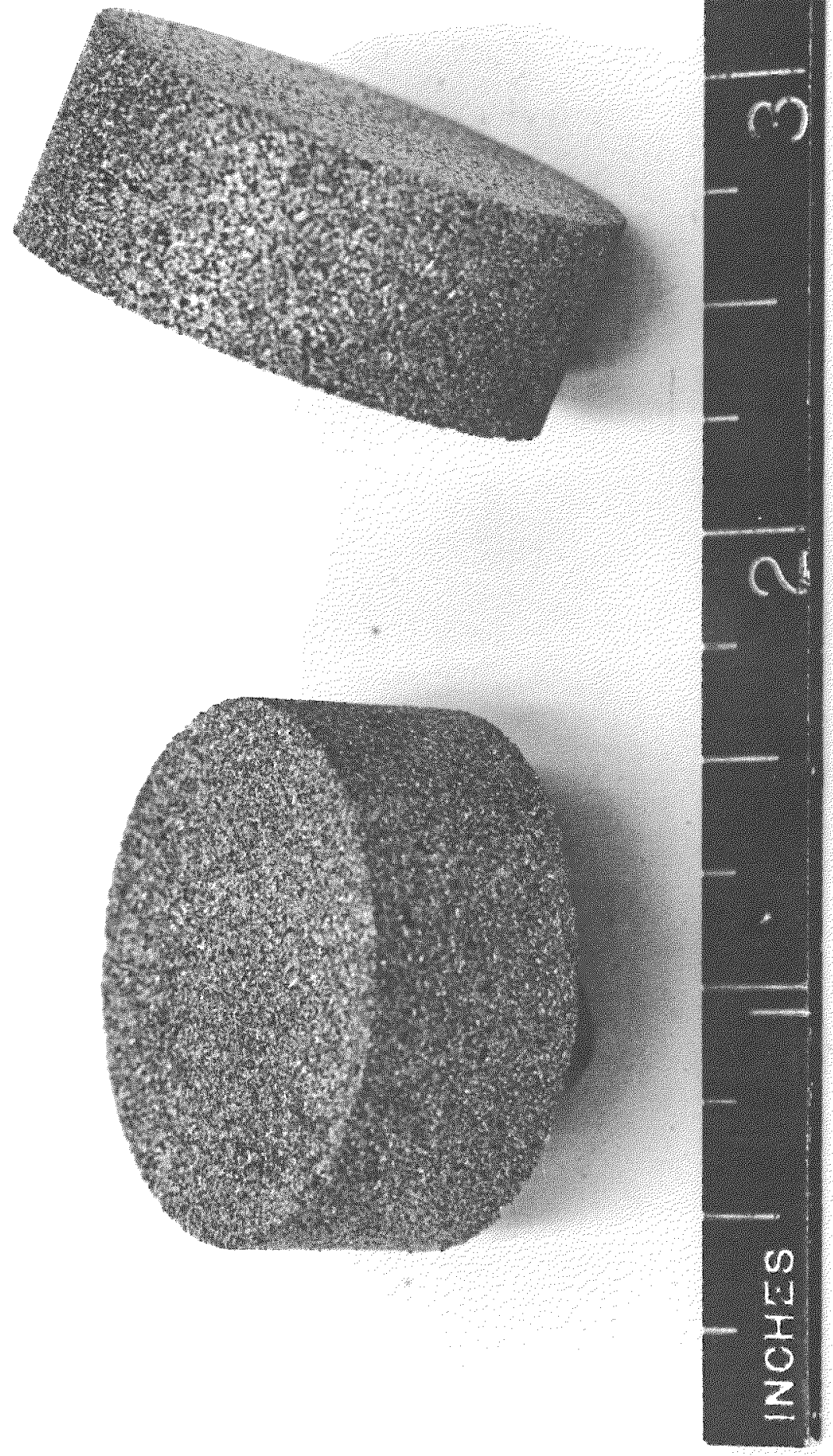

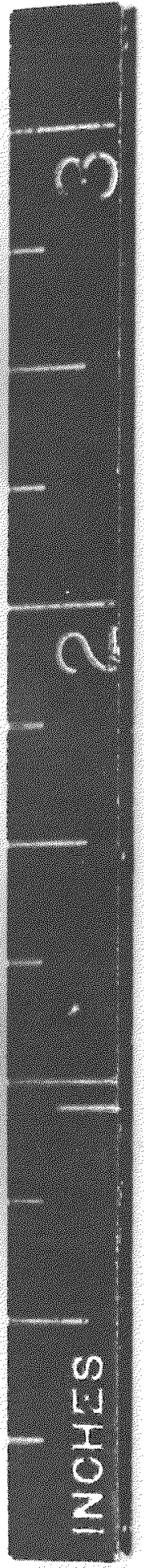

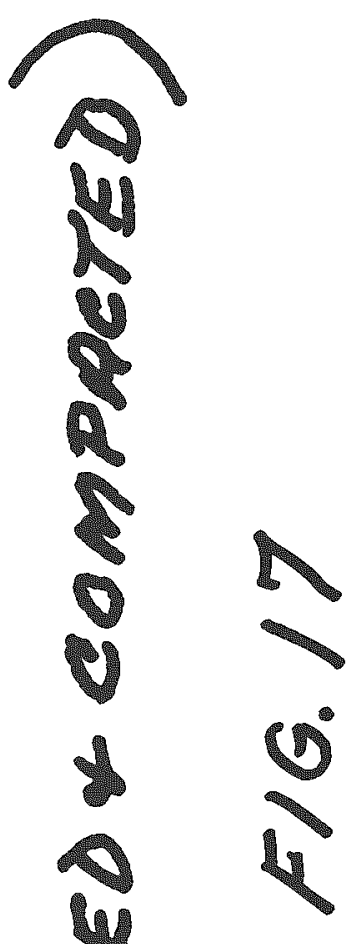

4
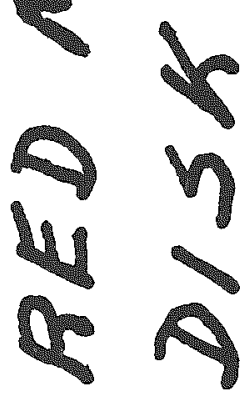

S

\&

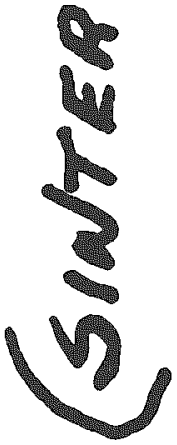




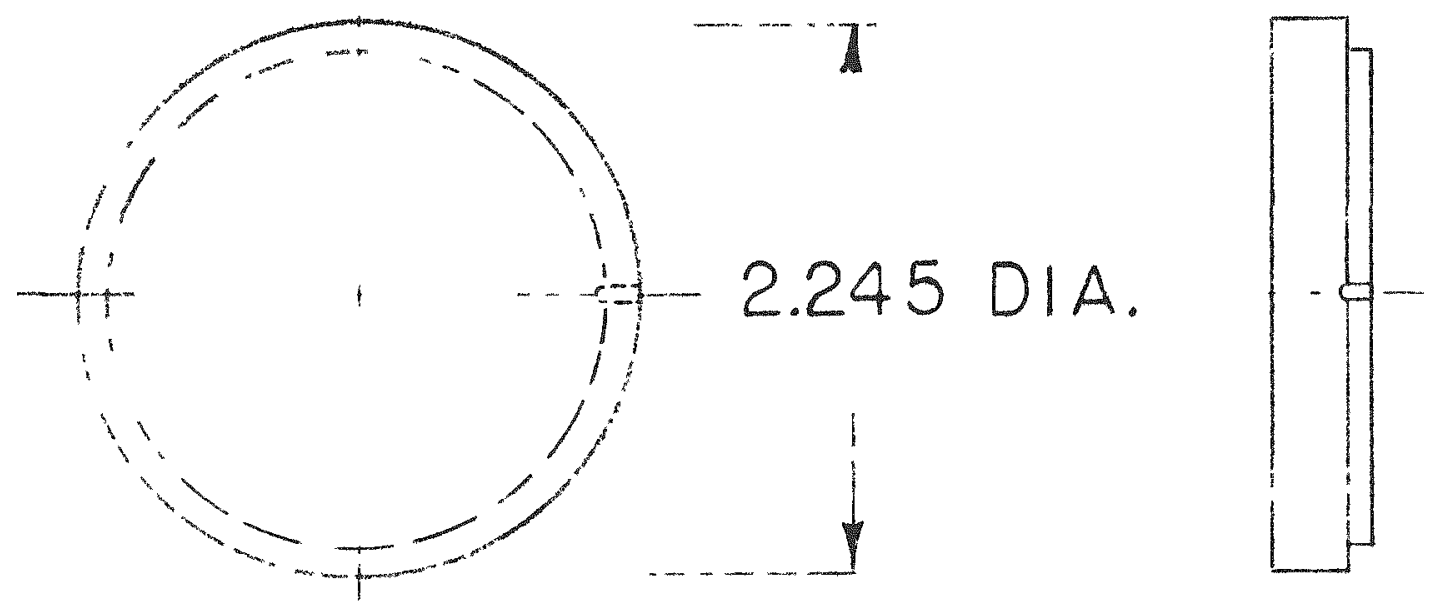

PRESSURE RELIEF HOLE IN TOP COVER

FIG. 18 


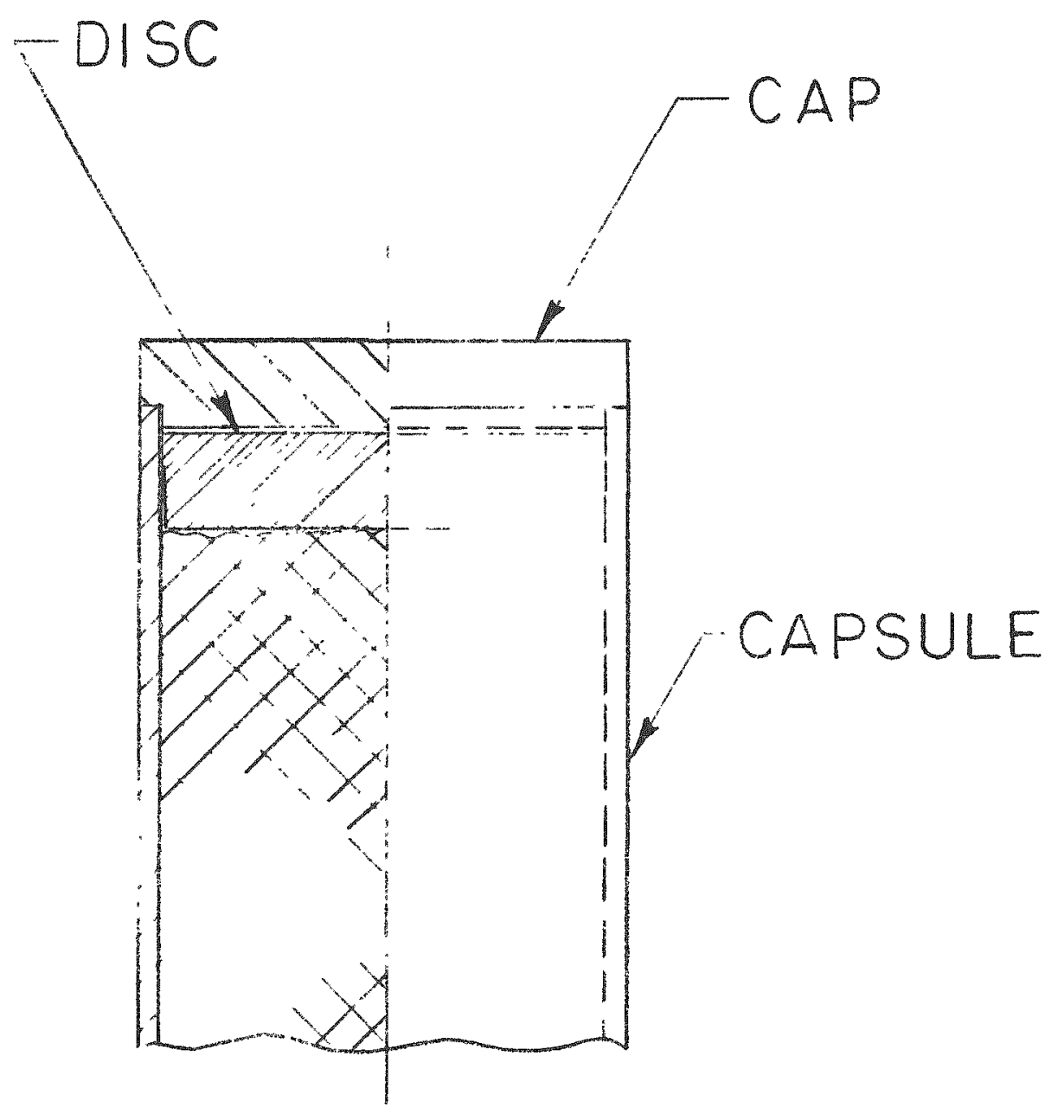

LOCATION OF
HELIUM STORAGE DISC
IN STRONTIUM CAPSULE

FIG. 19 

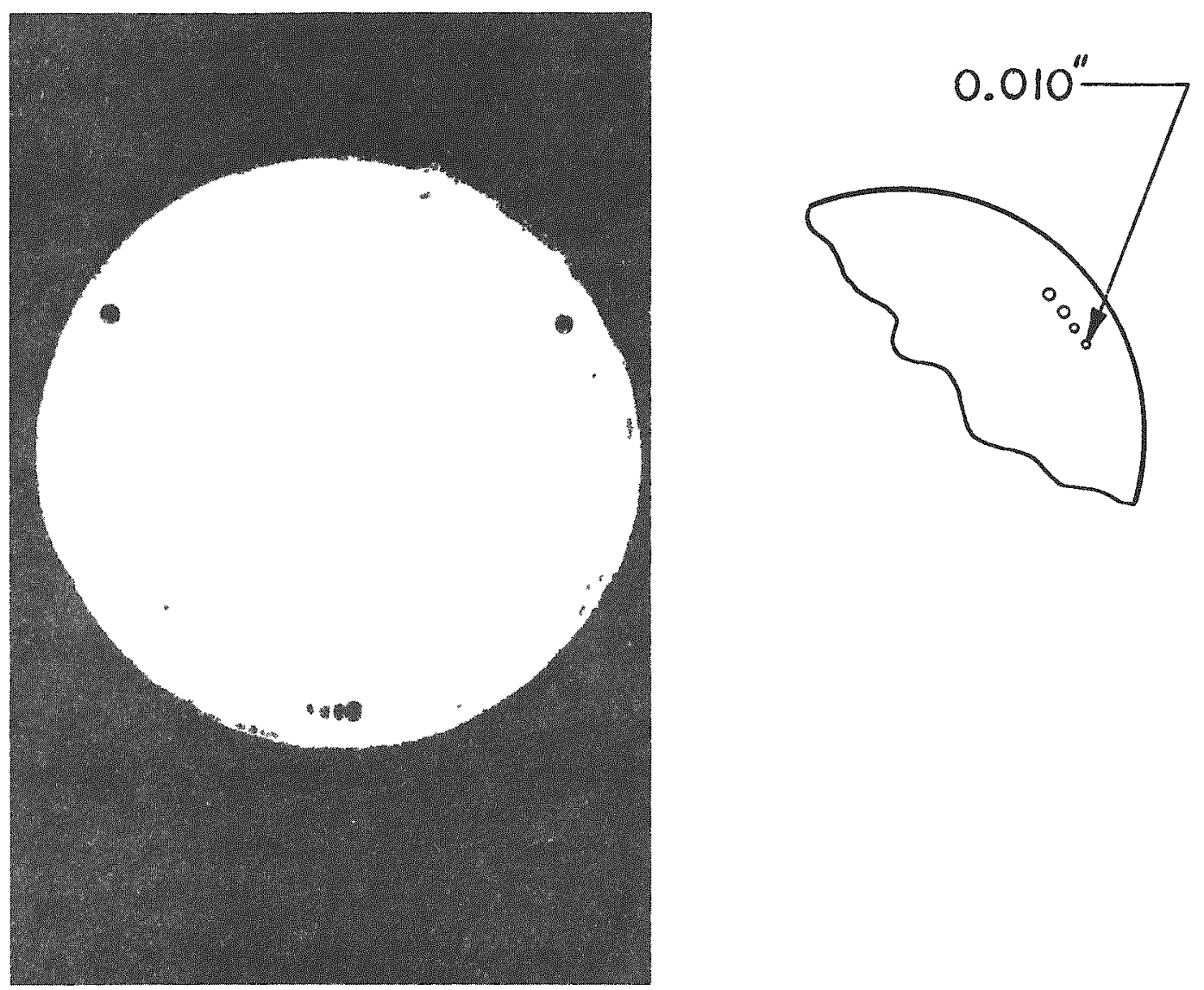

CALIBRATION XY-SCAN RECORD

FLAT BOTTOM HOLE DRILLED STANDARD

TYPE 316-L STAINLESS STEEL CAPSULE MATERIAL

FIGURE 20 

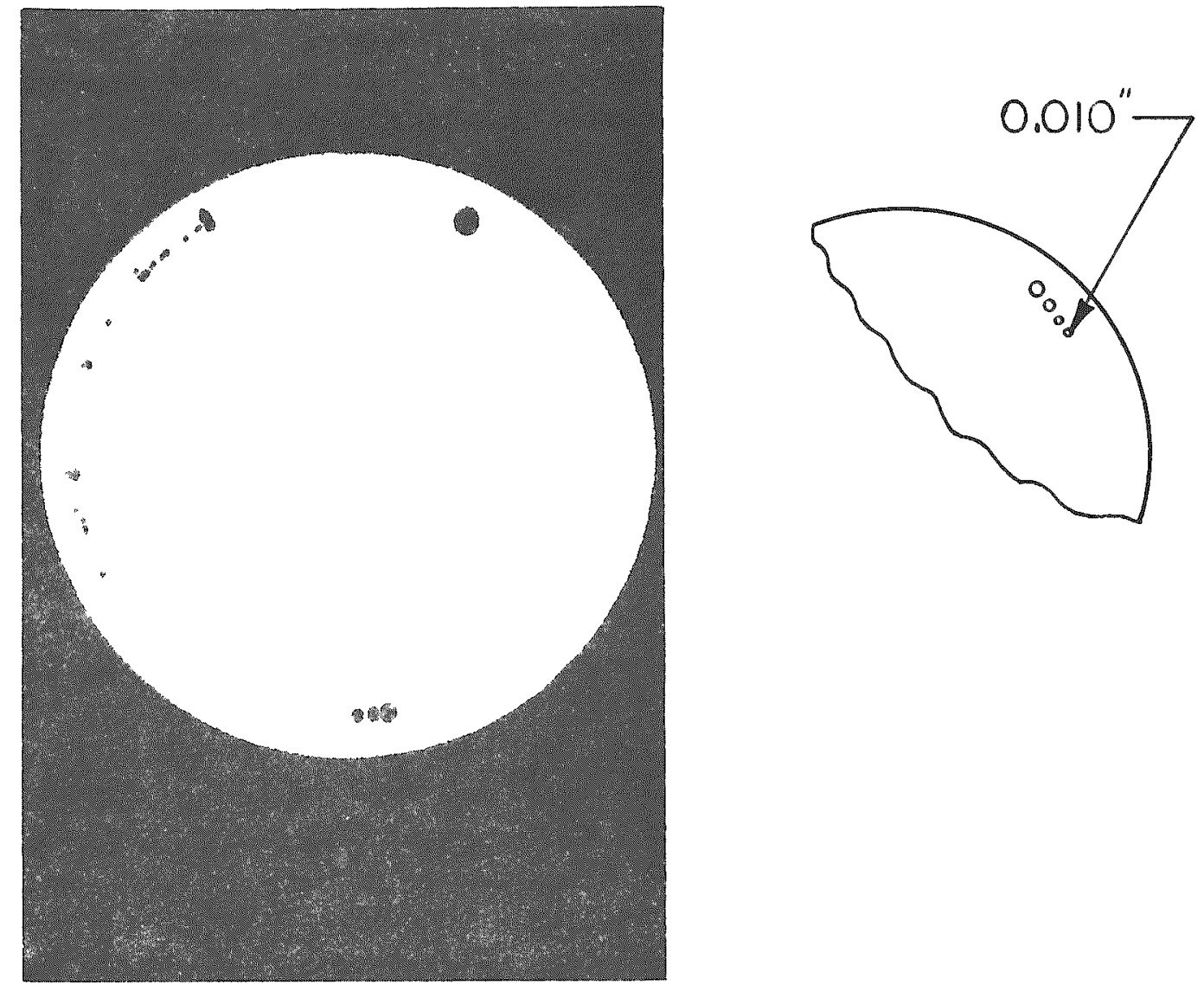

\section{CALIBRATION XY-SCAN RECORD \\ FLAT BOTTOM HOLE DRILLED STANDARD HASTELLOY C-276 CAPSULE MATERIAL}

FIGURE 21 

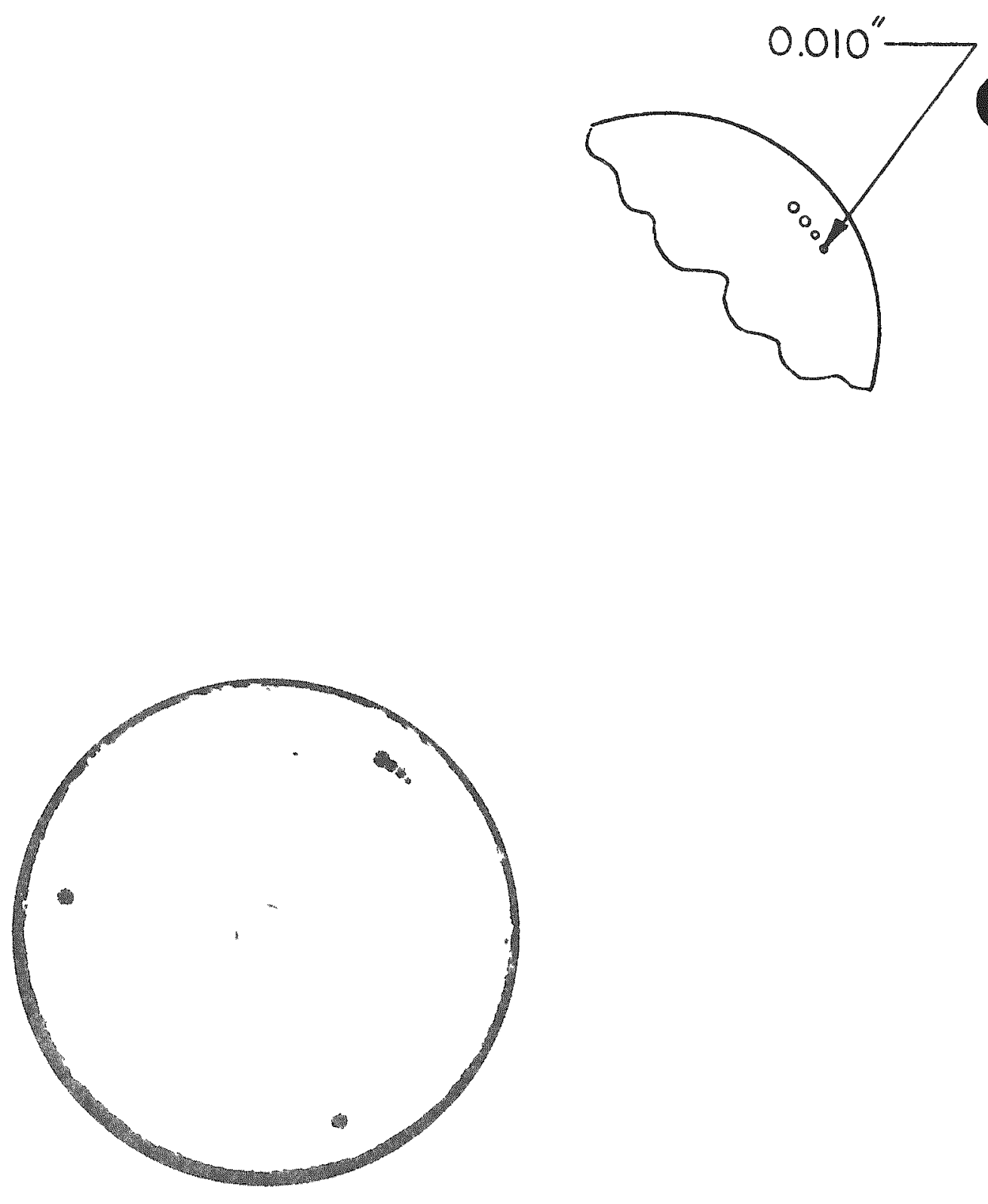

CALBRATION C-SCAN RECORD

FLAT BOTTOM HOLE DRILLED STANDARD TYPE 316-L STAINLESS STEEL CAPSULE MATERIAL

FIGURE 22 

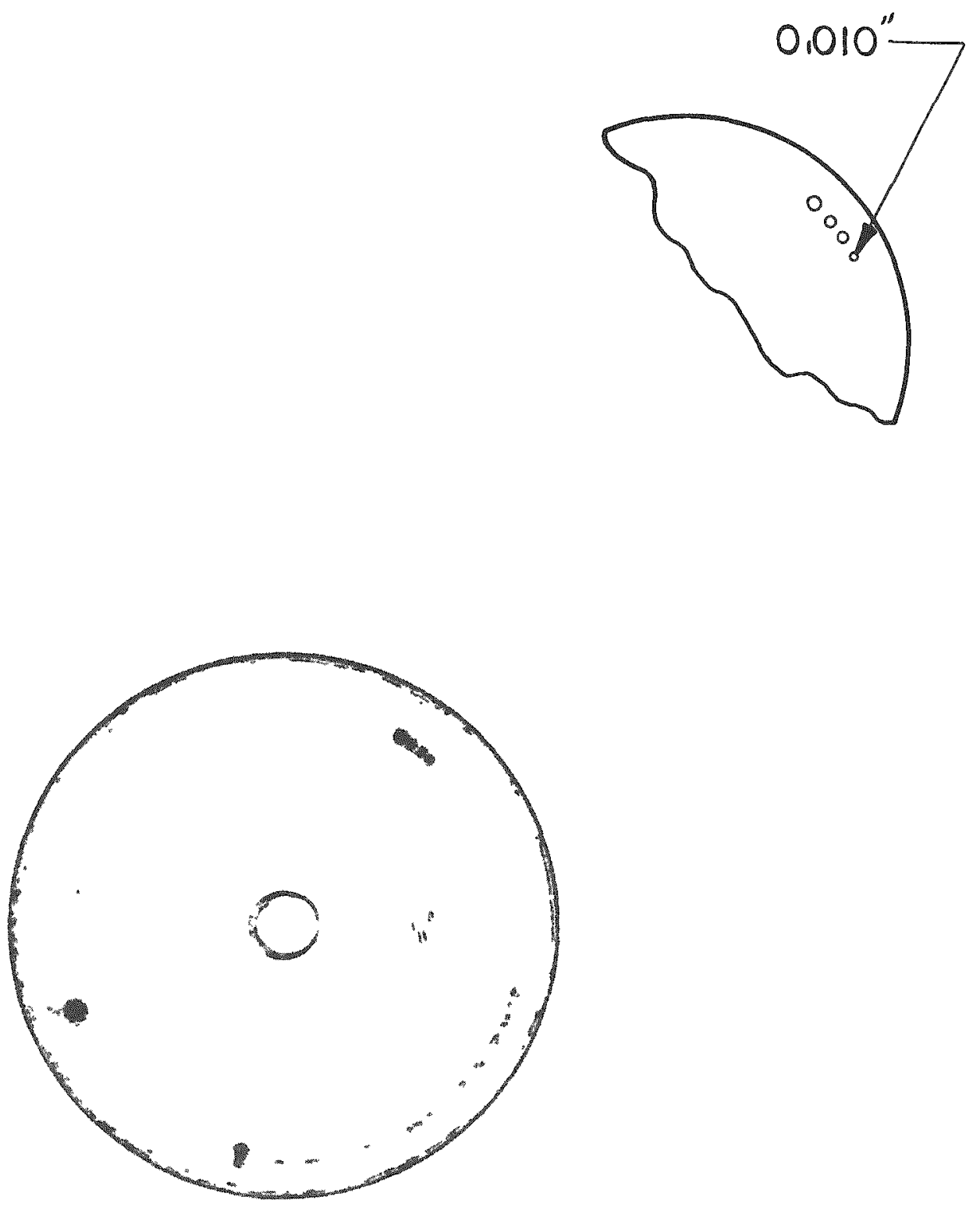

CALIBRATION C-SCAN RECORD FLAT BOTTOM HOLE DRILLED STANDARD HASTELLOY C-276 CAPSULE MATERIAL

FIGURE 23 